\title{
REVIEW PAPER ON HORIZONTAL SUBSURFACE FLOW CONSTRUCTED WETLANDS: POTENTIAL FOR THEIR USE IN CLIMATE CHANGE MITIGATION AND TREATMENT OF WASTEWATER
}

\author{
ENGIDA, T. ${ }^{1,2}-\mathrm{WU}, \mathrm{J} . \mathrm{M}^{{ }^{2 *}}-\mathrm{XU}, \mathrm{D} .^{2}-\mathrm{WU}, \mathrm{Z} . \mathrm{B} \cdot .^{12^{*}}$ \\ ${ }^{1}$ School of Resources and Environmental Engineering, Wuhan University of Technology, \\ Wuhan, P. R. China \\ (e-mail: zewedenahomruhama@gmail.com)
}

${ }^{2}$ State Key Laboratory of Freshwater Ecology and Biotechnology, Institute of Hydrobiology, Chinese Academy of Sciences, Wuhan, P. R. China

*Corresponding authors

e-mail/phone/fax:wuzb@ihb.ac.cn/+86-27-6878-0020/+86-27-6878-0675 (Z. B.Wu);

wujunmei@ihb.ac.cn (J.M.Wu)

(Received 25 $5^{\text {th }}$ Jul 2019; accepted $4^{\text {th }}$ Dec 2019)

\begin{abstract}
The combination of rapid urbanization and industrialization expansion increased waste volumes. Most of the wastewaters generated from either domestic or industrial sources are still discharged without adequate treatment processes, and impact on the environment and public health. The objective of this paper was to provide a comprehensive literature review on the application of horizontal subsurface flow constructed wetlands in treating a variety of wastewaters, discussing its feasibility in pollutant removal efficiency and additional benefit in climate change mitigation through carbon sequestration. The following results were obtained: $98 \%, 96 \%, 85 \%, 90 \%, 92 \%, 88 \%$ for BOD5, COD, TSS, TN, $\mathrm{NH}_{4}-\mathrm{N}, \mathrm{PO}_{4} 3-$ respectively in Kenya; $98.46 \%$ and $98.55 \%$ for COD and BOD5 in Indonesia; and ranges from 94-99.9\%, 91.7-97.9\% and 99.99\% for BOD5, COD and TFC respectively in Costa Rica. Whereas in Ethiopia, the HSSFCW achieved the following abatement efficiencies: COD ranges from 58 to $80 \%$, BOD ranges from 66 to $77 \%$, TKN ranges from $46-61 \%$, sulfates ranges from 53 to $82 \%$, and $\mathrm{NH}_{4}-\mathrm{N}$ range from 64 to $82.5 \%$ for tannery wastewater treatment. For domestic wastewater treatment; $99.3 \%, 89 \%, 855,84.05 \%, 77.3 \%, 99 \%$ and $94.5 \%$ were achieved for BOD5, COD, TSS, TN, $\mathrm{PO}_{4}{ }^{3}-$, TP, Sulfate, and TFC, respectively. In addition to improving water quality, CWs have a CSP. For example, CWs showed $\mathrm{CO}_{2}$ equivalent of $4119.54 \mathrm{~g} \mathrm{C} / \mathrm{m}^{2} / \mathrm{yr} \mathrm{CSP}$ (carbon sequestration potential) which is $15118.7118 \mathrm{~g} \mathrm{CO}_{2}$. The methane equivalent to this amount of carbon sequestration is 604.748472 $\mathrm{g} / \mathrm{m}^{2} / \mathrm{yr}$. Generally, research results indicated that constructed wetlands are efficient wastewater treatment techniques and should be encouraged for wastewater management as a strategy to reduce wastewater pollution. However, constructed wetland performance efficiency sustainability is affected by the operational conditions of HSSFCW including plant species, media/substrate types, water depth, hydraulic loading, and hydraulic retention time and feeding mode.
\end{abstract}

Key words: carbon sequestration potential, horizontal subsurface flow, climate mitigation, wastewater, constructed wetland, performance evaluation, and greenhouse gases, carbon cycle

\section{Introduction}

Globally, wetland ecosystems are more and more being used for the treatment and disposal of wastewater because they have been known as low-cost and operative treatment schemes (Brix et al., 2001). Their potential to advance the quality of water from inflow to outflow has been recognized (Donald, 1989) Constructed wetland schemes use a conglomerate of biological physical, and chemical parameters. The combination of rapid urbanization and industrialization expansion increased waste 
volumes. Most of the wastewater generated from either domestic or industrial sources are discharged still without adequate treatment processes. The discharging of untreated or partially treated wastewater by cities and industries causes an impact on the environment and public health resulting in the contaminated downstream water supplies becoming unfit for drinking, irrigation and recreational activities (Birhanu and Seyoum, 2007), due to the presence of nutrients, heavy metals, toxic organic pollutants and pathogens. Research reported by Bahri et al. (2008) also agreed that untreated wastewaters discharged into the freshwater bodies change the quality of freshwater. Besides deteriorating the freshwater bodies, the farmland soil characteristics are also changed due to using contaminated river waters or direct use of wastewater for irrigation. According to Bayrau et al. (2008) surveyed results in the case of Ethiopia outbreaks of waterborne diseases in addition to eutrophication of surface water and farmland resources are common.

The use of constructed wetlands for wastewater management is becoming more and more popular all over the world. This is due to its efficient wastewater management ability with cost-effective option in both developed and developing countries. Most of these systems are easy to operate, require low maintenance, and have low investment cost (Ballesteros et al., 2016; Langergraber, 2013). Today horizontal subsurface flow CWs (Constructed wetlands) are quite commonly used in many developed countries such as Germany, UK, France, Denmark, Australia, Poland and Italy. Constructed wetlands are also appropriate for developing countries but they are rarely investigated and implemented (Prasad et al., 2016). Water body deterioration is becoming a serious issue in developing countries due to indiscriminate discharge of wastewaters and lack of comprehensive management techniques. In developing countries constructed wetlands (CWs) are used to treat a wide variety of wastewaters such as domestic, municipal, industrial, landfill leachate as well as agricultural and highway runoff (Tilak et al., 2016). Wetland technologies are a reliable onsite wastewater treatment technology and work with a higher rate of biological activity which enables conversion of many of the pollutants that are contained in the wastewater into non-toxic byproducts and serve as secondary or tertiary treatment level that meets the regulatory standards. CWs have shown to successfully control macro (organic material, nutrients and pathogens) pollutants and provide high quality water used for irrigation, recreational and other reuse purposes. Generally, this technology serves as an active and low-cost alternative technology for the treatment of wastewater all over the world (Mustafa, 2013).

Treatment wetlands are technologies that are able to remove nutrients, toxic metals, organic pollutants, emerging contaminants and pathogenic organisms effectively (Belmont et al., 2009; Chen et al., 2012). Their effective pollutant removal is associated with several mechanisms involved in the constructed wetland systems. These are sedimentation, filtration, volatilization, adsorption, plant uptake and bacterial activity (Chazarenc et al., 2009; Ballesteros et al., 2016; Langergraber, 2013). The mechanisms of treatment in constructed wetland are complex processes which can happen simultaneously or sequentially involving microbial degradation, plant uptake, sorption, sedimentation, filtration and precipitation. In designing the good wetland, the main biological component in the CW is aquatic plants (macrophytes). However, it is important in determining the appropriate plant species that can survive in the wastewater environment, because only suitable plant species can treat a high concentration of pollutant in the waste water (Prasad et al., 2016). The selection of media type is also very important, because clogging problems are observed in subsurface flow constructed wetlands and linked hydraulic 
retention time and hydraulic conductivity. Therefore, adequate selection of granular media could decrease the estimated wetland area and improve the removal efficiencies (Lopez-Lopez et al., 2015). The vegetation biomass from the constructed wetlands can provide economic importance to communities by harvesting it for biogas production, animal feed, fiber for paper making and compost (Lakshman, 1987).

They also have an important role in carbon sequestration (CS) and reports indicated that the highest CSP (carbon sequestration potential) was recorded for Typha latifolia (741.02 $\mathrm{g} \mathrm{m}^{-2} / \mathrm{yr}$ ) followed by Phragmites australis $\left(740.5 \mathrm{~g} \mathrm{~m}^{-2} / \mathrm{yr}\right)$ and the lowest for Carexsp (137.37 $\mathrm{g} \mathrm{m}^{-2} / \mathrm{yr}$ ) from wetlands (Maqubool et al., 2013). Generally, CW can provide economical on-site wastewater treatment that is both effective and aesthetically pleasing (El-Gohary, 2008), and become a popular subject among many community leaders, health officials, and home owners. However, in developing countries the use of CWs is certainly lower in comparison to their use in Europe or the United States, despite the enormous potential and the great necessity of these countries to implement low-cost treatment for better wastewater management strategy to achieve the required standards (Belmont et al., 2004; Zurita et al., 2006, 2008). In order to establish the performance of constructed wetland systems under different conditions various research studies have been carried out to investigate constructed wetland systems in the removal of pathogens, organic matter and nutrients. To date however, very limited research works on the performance of $\mathrm{CW}$, especially under tropical conditions have been reported. Therefore, the purpose of this review paper was to provide a comprehensive literature review on the application of horizontal subsurface flow constructed wetlands in treating a variety of wastewaters, and to discuss its feasibility in pollutant removal efficiency and additional benefit in climate change mitigation through carbon sequestration.

\section{Objective}

This systematic review was aimed to assess and to provide a comprehensive literature review on the application of horizontal subsurface flow constructed wetlands in treating a variety of wastewaters, and to discuss its feasibility in pollutant removal efficiency and additional benefit in climate change mitigation through carbon sequestration.

\section{Method}

This review paper was written using searching key phrases "HSSF (Horizontal Sub Surface Flow) practice in the world", "Factors affecting treatment efficiency and "benefits and limitation of Constructed wetland" in springer link, science direct, library genesis, jester, and www.nap.org searching web pages. From these search results, peer reviewed journals and review papers were used. The interpretation of the result of each document was done using bar graphs, lines and scatter plot in a Microsoft Excel. In view of the current demand of this review, the performance assessment assignment employed a range of tools to gather and analyze data from secondary sources. The review approach considered and used specific indicator parameters that are important for the environment. The parameters used include: Total suspended solids (TSS), Total phosphors (TP), Total Kjeldahl nitrogen (TKN), Biological oxygen demand (BOD), Chemical oxygen demand (COD) and $\mathrm{NH}_{4}-\mathrm{N}$ (ammonia nitrogen). 


\section{Constructed wetland historical background}

Natural wetlands are usually found between water bodies and terrestrial areas. These systems naturally screen and collect pollutants such as silt and nutrients as they migrate towards water bodies. Natural wetlands were historically used as wastewater discharge sites (Kadlec, 2003). This system is still used for wastewater treatment under controlled conditions and the use of constructed wetlands has increased significantly. The purposeful construction and study of wetlands to treat wastewater was started at the Max Plank Institute in 1952 by Seidel (Vymazal, 2011).

Research in this area has accelerated since 1985 because of the simplicity of the systems regarding mechanical operation, biological complexity and high level of treatment. The other attractive advantage for developing countries is that construction may be completed using local materials and labor. The first full scale horizontal flow constructed wetland was constructed and used in the Netherlands in the 1975 but vertical flow wetlands dated back to the time of Seidel (Kadlec, 2008). Horizontal subsurface flow constructed wetland is the most widely used technology in Europe. This technology is designed typically in a rectangular bed form, and contains planted macrophytes and lined with an impermeable membrane or made from concrete. Mechanically raw or pretreated wastewater is fed in at the inlet and passes slowly through the filtration medium under the subsurface of the bed in a horizontal path until it reaches the outlet zone before discharging via level control arrangement at the outlet (Vymazal, 2005).

\section{Constructed wetland classification}

\section{General classifications}

Constructed wetlands for wastewater treatment are typically classified into two types according to the wetland hydrology, i.e. free water surface (FWS) constructed wetland and subsurface flow (SSF) constructed wetlands (Saeed and Sun, 2012).

In the FWS system, the water flowing through the system is exposed to the atmosphere, while in the SSF system, water is designed to flow through a granular media, without coming into contact with the atmosphere. FWS wetlands can be subdivided into four categories based on their dominant type of vegetation: emergent macrophyte, free floating macrophyte, free floating leaved macrophyte and submerged macrophyte. However, the subsurface flow wetlands (which by definition must be planted with emergent macrophytes) can be sub-classified according to their flow patterns: horizontal or vertical (Vymazal and Kröpfelová, 2008).

Surface flow systems are further subdivided based on the type of macrophytes that grow on them as free floating macrophytes (e.g. duck weed and water hyacinth), submerged macrophytes, free floating leaved macrophytes and floating mat macrophytes. FWS systems are similar to natural wetlands, with shallow flow of wastewater over saturated substrate. Whereas, in SSF systems, wastewater flows horizontally or vertically through the substrate which supports the growth of plants, and based on the flow direction, SSF constructed wetland is divided further into horizontal flow (HF) and vertical flow (VF) systems. A combination of various wetland systems was also introduced for the treatment of wastewater, and this design generally consisted of two stages of several parallel constructed wetlands in series, such as VF-HF CWs, HF-VF CWs, HF-FWS, CWs, and FWS-HF, CWs (Vymazal, 2013). In addition, the multiple- 
stage constructed wetlands that were comprised of more than three stages were used (Kadlec, 2008). In the recent years, enhanced artificial constructed wetlands such as artificial aerated CWs, baffled flow CWs, Hybrid towers CWs, step feeding CWs and circular flow corridor CWs have been proposed to enhance the performance of the system for wastewater treatment (Wu et al., 2014). According to Haberl (1999) design configurations of constructed wetlands are classified on the basis of the following parameters, as illustrated in Figure 1.

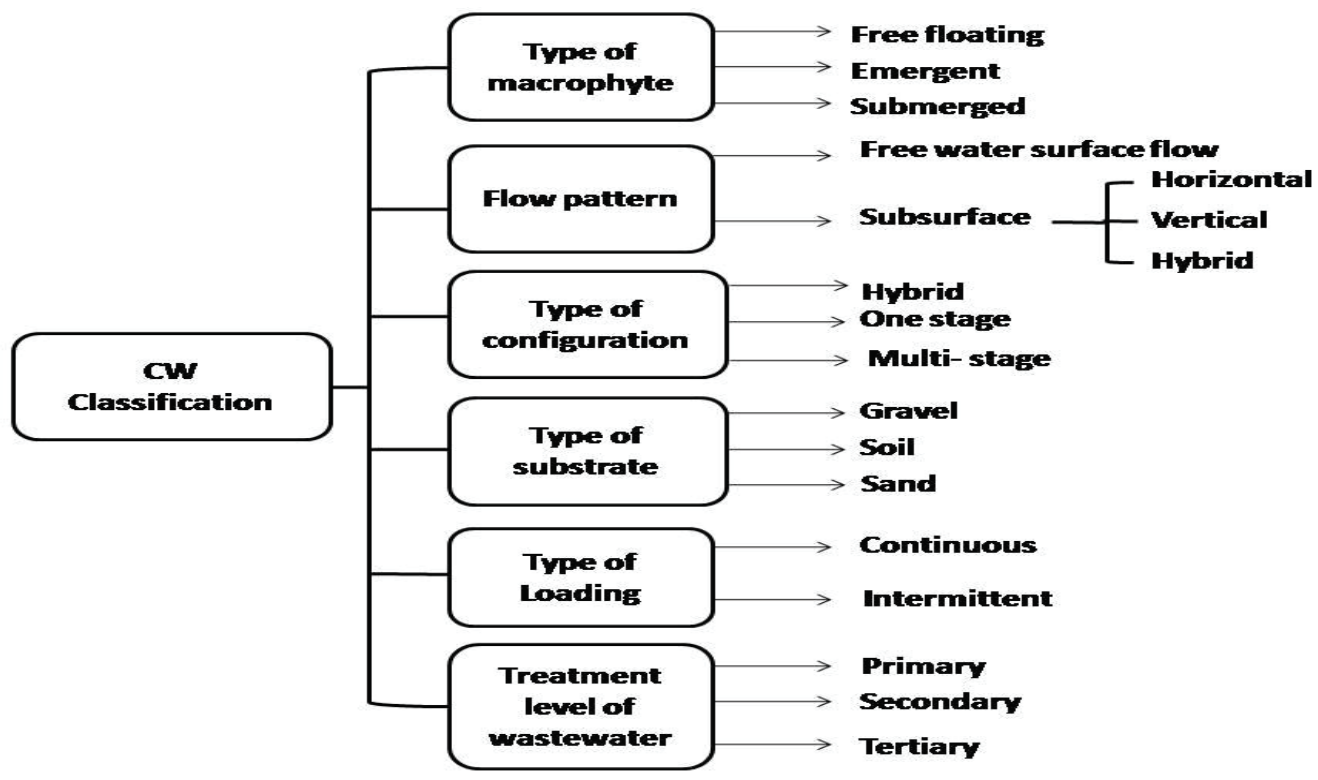

Figure 1. Classification and types of constructed wetland systems. Performance evaluation of constructed wetlands (Haberl, 1999)

\section{Performance evaluation of constructed wetlands}

Constructed wetlands are considered as natural treatment processes to stabilize, sequester, accumulate, degrade, metabolize and mineralize pollutants. They are used for a wide range of wastewater treatment such as municipal, domestic, agricultural, industrial, acid mine drainage, petroleum refinery wastes, compost and landfill leachates, and storm wastewaters (Vymazal, 2005). The treatment system involves macrophytes, substrates and microorganisms able to improve the water quality for reuse purposes. Macrophytes and Medias are an active component of horizontal subsurface flow constructed wetland (Vymazal, 2011). The selection of media type is also very important, because clogging problems are observed in subsurface flow constructed wetlands and linked hydraulic retention time and hydraulic conductivity (Lopez-Lopez et al., 2015).

Wastewater treatment is accomplished through the integrated combination of physical, biological and chemical interactions among biotic and abiotic components of the ecosystem and macrophytes cultivated in constructed wetlands make one of the basic components in the treatment process.

They influence plant microorganism's wastewater interactions by providing microbial attachment sites, sufficient wastewater residence time, trapping and settlement of suspended wastewater components as a result of resistance to hydraulic flow, surface area for pollutant adsorption, uptake and storage in plant tissue and diffusion of oxygen from aerial parts to the rhizosphere (Kyambadde et al., 2005). Wetlands remove metals using a 
variety of processes such as filtration of solids, sorption onto organic matter, oxidation and hydrolysis, formation of carbonates, formation of insoluble sulfides, binding to iron and manganese oxides, reduction to immobile forms by bacterial activity, and uptake by plants and bacteria. Metal removal rates in both surface flow and subsurface flow wetlands can be high, but can vary greatly depending upon the influent concentrations and the mass-loading rate (Vymazal, 2005).

A study conducted in Kenya to assess the effectiveness of $\mathrm{CW}$ in treating domestic wastewater showed that the removal of BOD5, TSS, COD, TN, NH4-N and Orthophosphate were highly effective with a removal value of $98 \%, 85 \%, 96 \%, 90 \%$, $92 \%$, and $88 \%$, respectively (Nyakango, 1999). This was mainly because this wetland consists of a combination of an SF system followed by three SSF wetland cells in a series adjacent to it. A case study conducted in Italy, to assess the treatment performance of an SSF CW by Pucci et al. (2000) showed high removal efficiencies for COD (93\%), TSS (81\%), hygienic parameters (TC 99\%, FC 99.7\%), but relatively low for nitrate (55\%), total nitrogen (50\%) and ammonium (30\%), and very low for total phosphorus $(20 \%)$. This is mainly due to poor nitrification and denitrification in the system. There is substantial evidence in the design of $\mathrm{CW}$ that a number of cells in series can consistently produce a higher quality effluent. Because this process minimizes the short-circuiting effects of any one unit and maximizes the contact area in the subsequent cell (Gearheart, 2004).

\section{Constructed wetland contaminant removal mechanisms}

Nitrogen removal mechanisms in wetland are nitrification in aerobic zone, denitrification in anaerobic zones which release $\mathrm{N}_{2}$ and $\mathrm{N}_{2} \mathrm{O}$ gases, plant uptake, sedimentation, decomposition, ammonia volatilization, and accumulation of organic nitrogen in gravels because of redox potential of hydric sediment conditions (Fig. 2).

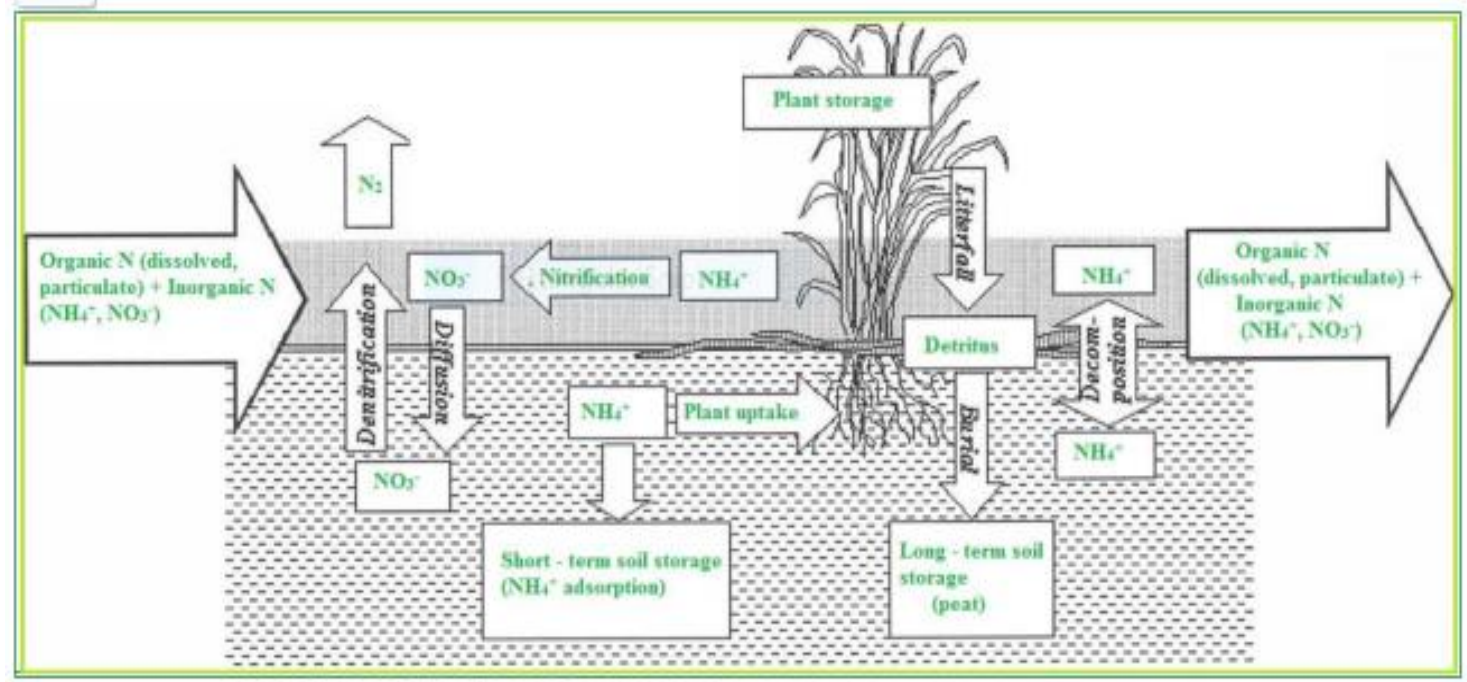

Figure 2. Nitrogen removal processes in wetland (Vymazal and Kröpfelová, 2008)

The fate of phosphorus is quite different in wetland soils, since there are no mechanisms comparable to de-nitrification as phosphorus has no gaseous phase. 
Consequently, plant uptake, sorption, decomposition and long-term storage occur, and then phosphorus tends to accumulate in wetlands. Precipitation of phosphate minerals can provide a significant sink for phosphorus in wetlands with large stores or inputs of iron and aluminum or calcium (Fig. 3) (Vymazal and Kröpfelová, 2008).

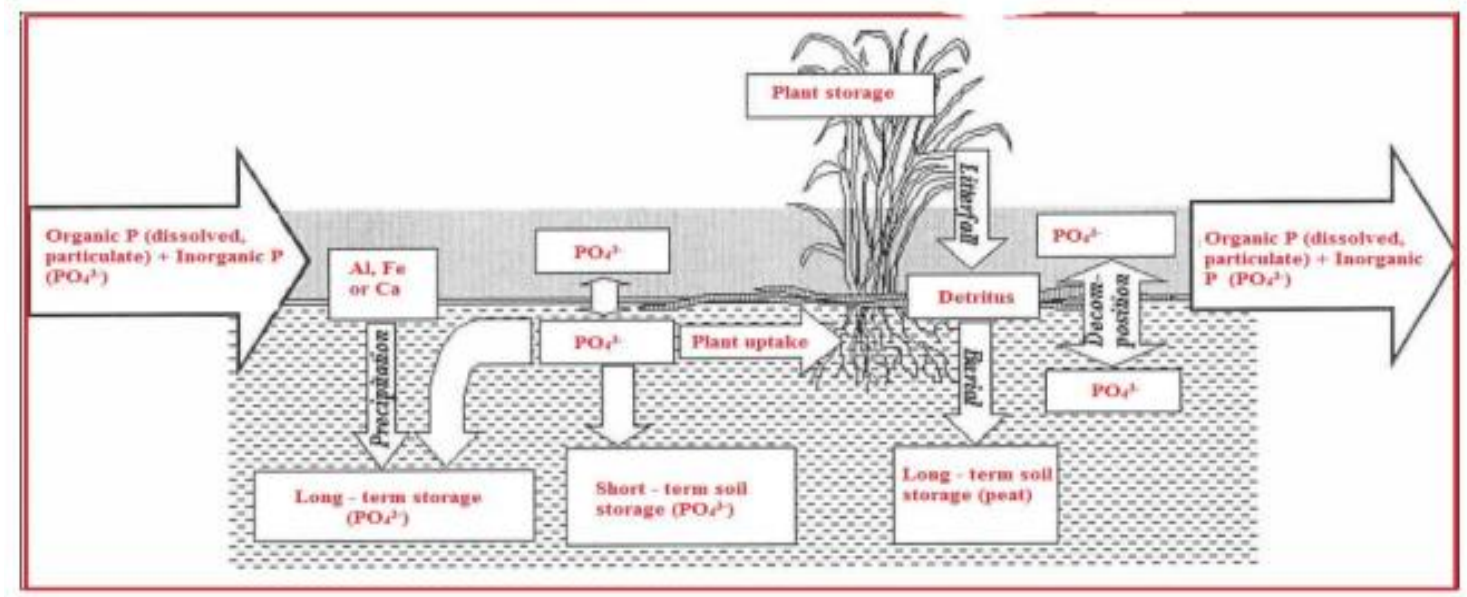

Figure 3. Phosphorus removal mechanisms (Vymazal and Kröpfelová, 2008)

The wetland treatment mechanism is a dynamic process acting wastewater purification under the cooperation of emergent macrophytes, substrates and attached microorganisms. In general, in constructed wetlands it is important to study biomass accumulation and nutrient flux in order to understand the dynamics of nutrients. The carbon cycle in wetlands has been investigated to understand the linkage between biomass generation and carbon sequestration (Kayranli et al., 2010). Wastewater treatment may also serve as a carbon sequestration offset (Rosso and Stenstrom, 2008). Wetland ecosystems are acting as a net carbon emission and sequestration systems depending on the time scale and hydrology operational strategies (Whiting et al., 2001), and as a component of a larger system treating wastewater (Rosso and Stenstrom, 2008). Constructed wetlands are passive natural processes and avoid carbon emission equivalent of $1.3 \mathrm{Mt} \mathrm{C} / \mathrm{yr}$ for every 1.0 MGD as compared to conventional high rate treatment facilities such as activated sludge. There are many mechanisms for the capture and release of carbon in a wetland (Fig. 4). Pathways for the release of carbon in the constructed wetland system are slow decomposition, respiration, and physical removal. Photosynthesis is the process whereby a plant transforms atmospheric carbon in the form of $\mathrm{CO}_{2}$ into the carbon of the plant tissue or biomass. The process of plant respiration releases some $\mathrm{CO}_{2}$ to the atmosphere as a byproduct of cellular growth. In addition to respiration, plants release carbon as a byproduct of decomposition in the form of $\mathrm{CO}_{2}$ and $\mathrm{CH}_{4}$ (Burke, 2011).

\section{Factors affecting the performance of constructed wetlands}

\section{Temperature}

This is a key environmental factor that determines the activity of nitrifying bacteria and the de-nitrification potential in treatment wetlands (Langergraber, 2013). Nitrogen removal by biological means is most efficient at $20-25{ }^{\circ} \mathrm{C}$ and temperatures above this 
affect both microbial activity and oxygen diffusion rates in the constructed wetlands. The microbial nitrification and de-nitrification activities can decrease considerably at water temperatures below $15^{\circ} \mathrm{C}$ or above $30^{\circ} \mathrm{C}$, and most microbial communities for nitrogen removal function at temperatures greater than $15^{\circ} \mathrm{C}$ (Kuschk et al., 2003). Literature revealed that the activity of de- nitrifying bacteria in constructed wetland sediments is generally more robust in spring and summer than in autumn and winter and the overall removal rate of nitrate is higher in the summer than in winter (Oostrom, 1994). Denitrification is commonly believed to cease at temperatures below $15^{\circ} \mathrm{C}$, but some studies have demonstrated de-nitrification activity at $14{ }^{\circ} \mathrm{C}$ or lower temperatures. Richardson et al. (2004) reported that the optimum temperature range for nitrification is $30-40{ }^{\circ} \mathrm{C}$ in soils and the optimal ammonification is carried out at $40-60{ }^{\circ} \mathrm{C}$ at the optimal $\mathrm{pH}$ between 6.5 and 8.5. At low temperature, nitrification is insufficient to prevent a net increase in ammonia concentration due to ammonification (Akratos and Tsihrintzis, 2007).

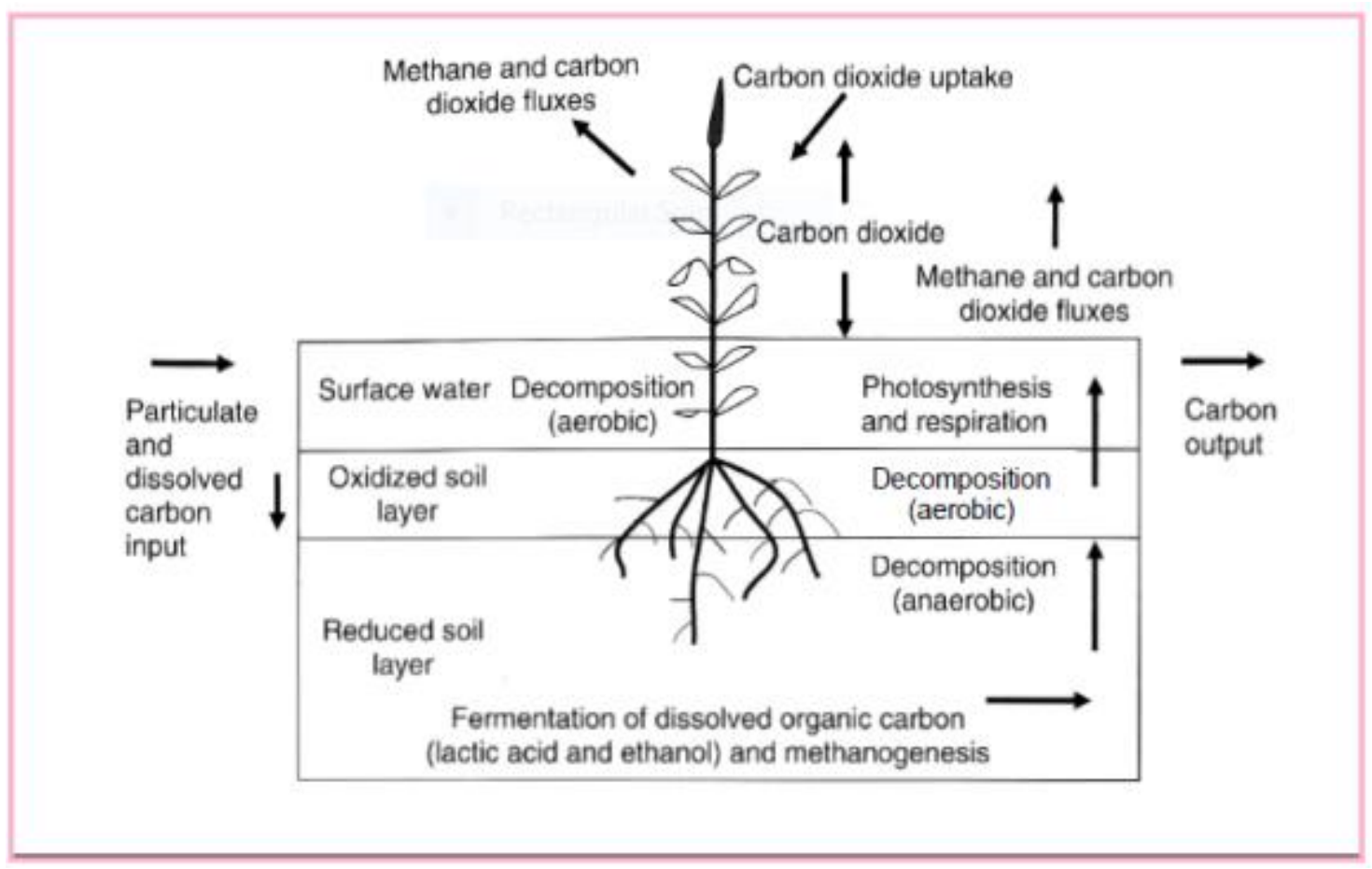

Figure 4. The carbon cycle (Kayranli, 2010)

HRT

The high purification efficiency of constructed wetlands can be achieved by choosing suitable growth media. Particle size, surface nature, bulk porosity and pore spaces of the growth media are important factors in selection of media type for wastewater treatment. Growth media provide not only physical support for plant growth but also additional sites for biofilm growth and the adsorption of nutrients, heavy metals and promote the sedimentation and filtration of pollutants. In general, the inconsistent treatment efficiency of constructed wetlands depends on the type of feeding mode, the plant types and type of media used (Abdelhakeem et al., 2016). According to Huang et al. (2000) explanation, ammonium and total Kjeldhal Nitrogen (TKN) concentrations in treated effluent decreased diagrammatically with increased wastewater retention time. In most 
wetland systems, efficient nitrogen removal requires longer retention time compared with organic matter (COD and BOD) removal efficiency. Accordingly, nitrogen removal efficiency varies greatly with flow conditions and HRT (Taylor et al., 2006).

In subsurface constructed wetlands, media perform the function of rooting material for macrophytes surface for microbial biofilm growth, screen organic and inorganic suspended matter, and distribute inflow and collect outflow water (U.S. EPA, 1993). Keeping the water level below the surface of the bed, this reduces the risk of human contact with pathogens, and reduces the opportunities for breeding vector organisms such as mosquitoes. Media can also provide adsorption sites for phosphorus (Kadlec, 2003). According to this researcher, potentially active industrial byproduct substrates include blast furnace slag, crushed rock, fly ash, and crushed concrete, burnt oil shale, iron ochre and wood chips. The microorganisms responsible for the degradation of pollutants are located at the surface of the media and the smaller sized media has a larger surface area than the coarser media (Vymazal and Kröpfelová, 2008).

Well graded media (containing all gravel sizes in the selected range) is better than poorly graded media as it offers greater pore space and provides good removal of particulate matter. In general, the substrate alone also provides significant wastewater treatment, but vegetation further improves treatment efficiency (Abdelhakeem et al., 2016). Therefore, the high purification efficiency of constructed wetlands can be achieved by choosing suitable growth media.

\section{Types of plant species}

Plants are often grown in gravel beds to stimulate uptake and create suitable conditions for the oxidation of the substrate, thereby improving the ability of the system to treat the wastewater and create aesthetic value, exhibit several properties which enhance wastewater treatment processes and thus, make them an essential component of the treatment wetland. These properties influence wastewater treatment through physical effects such as filtration, provision of surface area for the growth and attachment of microorganisms and regulation of undesirable water temperature as well as surplus algal growth. Macrophytes are the main biological component of wetlands and their presence has been hypothesized to play a key role in wastewater remediation (Luckeydoo et al., 2002). Macrophytes are also play an important role in wastewater treatment through uptake of nutrients, surface bed stabilization and other mechanisms (Kadlec, 2008). Wetland plants must survive the potentially toxic effects of the effluent and enhance the treatment process of wetlands in several ways such as filtering wastes, regulating flow, providing surface area for microbiological treatment, providing shed and controlling algae growth, contributing oxygen to the cells, taking up and storing some metals and nutrients from the wastewater (Kyambadde et al., 2005).

Metabolically, plants take up pollutants; produce organic carbon and oxygen, thereby improve the water to varying extents. They are not only assimilating pollutants directly into their tissues, but also act as catalysts for purification reactions by increasing the environmental diversity in the rhizosphere, promoting a variety of chemical and biological reactions that enhance purification. Several studies have shown that plants enhance treatment efficiency by providing a favorable environment for the development of microbial populations and by oxygenating the system. The roots of macrophytes provide surface areas for microbial growth and aerobic zones in constructed wetlands. The root facilitates various physical and biochemical processes caused by the relationship of plants, microbial communities, soil and contaminants. Wetland systems with 
vegetation typically remove greater amounts of total nitrogen than non-vegetated systems (Taylor et al., 2006). Nutrient removal by the emergent plants is achieved by two processes: absorption of the plant itself and microorganism activity around the rhizome (Cooper and Boon, 1987). In general, the main role of macrophytes in constructed wetlands is to promote microbial growth with the media surfaces, and to assist the permeation velocity of the wastewater for pollutant treatment efficiency (Table 1).

Table 1. Pollutant removal processes in surface flow constructed wetland (Tousignant and Fankhauser, 1999)

\begin{tabular}{|c|c|}
\hline Pollutant type & Removal process \\
\hline $\begin{array}{l}\text { Organic material } \\
\text { (COD and BOD) }\end{array}$ & $\begin{array}{c}\text { Particular organic matter is removed by settling and filtration then converted to } \\
\text { soluble BOD } \\
\text { Soluble organic matter is fixed by biofilms and degraded by attached bacteria in the } \\
\text { biofilm on stems, roots sand particles etc. }\end{array}$ \\
\hline $\begin{array}{l}\text { Suspended solids } \\
\text { (TSS) }\end{array}$ & $\begin{array}{c}\text { Filtration } \\
\text { Decomposition by bacteria during long retention time }\end{array}$ \\
\hline Nitrogen & $\begin{array}{l}\text { Nitrification and de-nitrification in biofilm } \\
\text { Plant and microbial uptake }\end{array}$ \\
\hline Phosphorus & $\begin{array}{l}\text { Adsorption (retention in the media) } \\
\text { Precipitation with } \mathrm{Ca}, \mathrm{AL} \text { or } \mathrm{Fe}\end{array}$ \\
\hline Pathogens & $\begin{array}{l}\text { Filtration, adsorption, predation (feeding) by protozoa } \\
\text { Die-off due to long retention times }\end{array}$ \\
\hline Heavy metals & $\begin{array}{c}\text { Precipitation and adsorption } \\
\text { Plant uptake } \\
\end{array}$ \\
\hline $\begin{array}{c}\text { Organic } \\
\text { contaminates }\end{array}$ & $\begin{array}{c}\text { Adsorption by biofilm and clay particles } \\
\text { Decomposition due to long retention time and by bacteria }\end{array}$ \\
\hline
\end{tabular}

\section{Other factors}

Other important factors are wetland depth, $\mathrm{pH}$, and $\mathrm{DO}$. The nitrification and denitrification process depend upon water $\mathrm{pH}$, the presence or depletion of dissolved oxygen, hydraulic loading rate, and the hydrological period of the wetland. At low DO concentration, nitrification occurs in the aerobic zone but denitrification occurs in the anoxic zone (Kadlec, 2008). The biofilm may improve the denitrification; because of algae provide a desirable carbon source for denitrifies (Mariñelarena and Di Giorgi, 2001). In general, in order to maintain and improve nitrogen removal and water quality in constructed wetlands, attention should be given to factors that promote the growth rate of macrophytes and bacteria, such as planting depth, harvesting time, optimization of temperature, $\mathrm{pH}$, DO and HRT.

\section{Performance efficiency of horizontal sub surface flow constructed wetland (HSSFCW): a case in other countries}

This section presents different macrophytes used for treatment of wastewater in constructed wetland and their effectiveness in treating wastewater pollutants. The focus of each case study is according to parameters related to the overall constructed wetland design, macrophyte species, hydraulic loading rates and the efficiency of pollutant removal. In order to evaluate the performance efficiency of a $\mathrm{CW}$ unit, the percentage of concentration reduction and mass removal is reported. The wetland effluent is being 
irrigated on vegetation, nutrient levels in the effluent do not need to be as strict as for direct discharge into a water course (Tousignant and Fankhauser, 1999). These systems are highly effective at improving water quality have many benefits such as habitat creation and low-cost operations (Kadlec, 2008). According to Mustafa (2013), the monitoring of horizontal flow constructed wetland indicates that the general performance of the system was good and it successfully reduced pollutants even under fluctuating pollutant loading resulting from power breakdown. The average reduction of BOD concentration over the treatment periods was $50 \%$ with mean effluent concentration of 34 $\mathrm{mg} / \mathrm{L}$. Whereas, the average removal efficiency of the treatment system for COD, TSS, ammonia-nitrogen, orthophosphate and fecal coliform were 44\%, 78\%, 49\%, 52\% and $98 \%$ with mean effluent concentrations of $68.3 \mathrm{mg} / \mathrm{L}, 45 \mathrm{mg} / \mathrm{L}, 9.7 \mathrm{mg} / \mathrm{L}, 3.7 \mathrm{mg} / \mathrm{L}$ and $3.0 \times 10^{3} \mathrm{CFU}$ (Colony-forming units)/100 $\mathrm{ml}$ respectively.

In general, the monitoring of horizontal flow constructed wetland indicates that it was good and successful in reducing pollutants from wastewater up to the required standards even under fluctuating pollutant loading. The outcomes revealed that if constructed wetlands are properly planned and operated, they can be used as secondary or tertiary treatment level under local conditions and finally delivers high value water that can be used for landscape irrigation and also for other helpful uses. The COD removal efficiency of HSSFCW even at low concentration which might be due to high degradation rate in the wastewater collection systems and in settling tank before entering the CWs. In overall, the results obtained in Indonesia, Thailand, and Costa Rica revealed that, the local macrophytes and local natural substrates can perform successfully in the treatment of domestic wastewater (Table 2). The organic contaminants and pathogens can be removed successfully, therefore, the treated water can be used safely for irrigation, fishery or out-door uses. In addition, the treated water can replace a part of the fresh water need supplied from the pipe distribution systems and be potential to protect surface and ground water reduces from the pollutants. Moreover, the use of macrophyte creates a green space in a single house yard or green public views for neighborhood (Qomariyah et al., 2017).

Table 2. The effective removal of pollutants in CWs with local macrophytes and natural substrates (Qomariyah et al., 2017)

\begin{tabular}{|c|c|c|c|c|}
\hline $\begin{array}{c}\text { Type and size of } \\
\text { CW }\end{array}$ & Type plant & $\begin{array}{c}\text { Type of } \\
\text { substrate }\end{array}$ & Country & $\begin{array}{c}\text { Removal } \\
\text { efficiency }(\%)\end{array}$ \\
\hline $\begin{array}{c}\text { HSSFCW } \\
(1.7 \times 0.7 \times 0.7 \mathrm{~m})\end{array}$ & C. papyrus & Sand \& gravel & Indonesia & $\begin{array}{c}\mathrm{BOD}=98.55 \% \\
\mathrm{COD}=98.46 \% \\
\mathrm{TSS}=88-96 \% \\
\text { Detergent }=99.86 \%\end{array}$ \\
\hline $\begin{array}{c}\text { HSSFCW } \\
(2 \times 1 \times 1 \mathrm{~m})\end{array}$ & Canna \& Helicona & Gravel & Thailand & $\begin{array}{c}\mathrm{BOD}=94-99.9 \% \\
\mathrm{COD}=42-83 \% \\
\mathrm{TSS}=88 \%-96 \% \\
\mathrm{TN}=4-37 \% \\
\mathrm{TP}=6-35 \%\end{array}$ \\
\hline $\begin{array}{c}\text { HSSFCW } \\
(14 \times 1.2 \times 0.6 \mathrm{~m})\end{array}$ & Coix lacrymajodi & Crushed rock & Costa Rica & $\begin{array}{c}\mathrm{BOD}=94-99.9 \% \\
\mathrm{COD}=91.7-97.9 \% \\
\mathrm{FC}=99.99 \%\end{array}$ \\
\hline
\end{tabular}


The performance efficiency of subsurface flow constructed wetland in Italy done by Pucci et al. (2000) indicates that it has high removal efficiency for COD (93\%), TSS $(81 \%)$ and total coliform (99\%), but relatively less removal for nitrates $(55 \%)$, total nitrogen $(50 \%)$, ammonium $(30 \%)$ and total phosphorus $(20 \%)$. This is mainly due to poor nitrification and denitrification in the treatment system. A study done in Kenya also revealed that the effectiveness of the constructed wetland in treating domestic wastewater and indicated a removal efficiency of $98 \%, 85 \%, 96 \%, 90 \%, 92 \%$ and $88 \%$ for BOD5, TSS, COD, TN, $\mathrm{NH}_{4}-\mathrm{N}$ and $\mathrm{PO}_{4}$ respectively (Nyakango, 1999). This achievement was due to the wetland design which consists of a combination of a surface flow system followed by three subsurface flow wetlands in a series adjacent to it.

The removal efficiency of constructed wetlands varies with hydraulic retention time, hydraulic loading, wetland design, temperature, substrate and vegetation. Although considerable number of reports has contributed to our understanding of the physical, chemical and biological processes that facilitate the removal process, inconsistence results suggest that further studies are required to optimize the system functioning. For example, many scholars show that, a wetland scheme with vegetation has advanced efficiency of removal than that without plants (Bwire et al., 2011) although others did not notice any significant change between planted and unplanted systems (Baldizon et al., 2002). Similarly, the percentages of nutrient (nitrates/nitrites and phosphates) removal obtained in the planted constructed wetland cell were higher than the averaged percentages of nutrient removal rates in the unplanted cell.

Thus, the average nitrate/nitrite percentage removal was $58.1 \%$ for planted cells and $21.6 \%$ for unplanted cell while the phosphate percentage removal averaged $40.1 \%$ for planted cells and 5.2\% for unplanted cell (Mairi et al., 2012). Bacteria may be reduced by sedimentation, chemical reactions, natural die-off and predation by zooplankton, nematodes, lytic bacteria and attacks by bacteriophages (Denny, 1997). The role of plants related to the treatment of wastewater is the physical effects brought about by the presence of the plants. The macrophytes alleviate the surface of the beds, offer good condition for physical filtration and deliver enormous surface area for attached microbial growth (Brix and Schierup, 1989). Furthermore, macrophytes reduce the velocity of wastewater into the wetland system and also supply oxygen at the root zone which is used by aerobic microbes, thereby enhancing purification process of wastewater in addition to purification done by anaerobic microbes (Watson et al., 1989).

The performance efficiency of different constructed wetland systems that contain different HRT, substrate, plant species and wastewater type were reviewed in order to regulate the performance of constructed wetland parts in elimination of contaminants. The influent and effluent concentrations including percentage removal were summarized in Table 3.

Table 3. HSSFCW percentage abatement in different locations planted with Phragmites australis

\begin{tabular}{c|c|c|c|c|c|c|c}
\hline Location & BOD $_{5}$ & COD & TSS & TN & NH $_{4}$ & TP & Reference \\
\hline Egypt & 93 & 91 & 92 & 60 & 57 & 63 & Puigagut, 2007 \\
Spain & 74.2 & 66 & 87.8 & 56.5 & 45.7 & 45 & Barbera, 2009 \\
Italy & 74 & 60 & 89 & 35 & - & 57 & Kotti, 2010 \\
Greece & 76 & 64 & - & 55 & 43 & 48 & El Hamouri, 2007 \\
\hline
\end{tabular}


As indicated in Table 4, the nitrogen removal in constructed wetlands depends upon system design, environmental chemistry (roots, plants, water and sediments), plant uptake, available carbon and material type. The mean removal efficiency of the planted (reeds) and unplanted constructed wetlands during the three months of warm and cold study periods are indicated in Figure 5. In general, proper performance and high removal at the first treatment unit (septic tank) increases the efficiency of the treatment plant (Farzadkia et al., 2015).

Table 4. Treatment efficiency of HSSFCW in different countries

\begin{tabular}{|c|c|c|c|c|c|c|c|}
\hline $\begin{array}{c}\text { Type of waste } \\
\text { water }\end{array}$ & $\begin{array}{l}\text { Type of } \\
\text { media }\end{array}$ & Plant type & HLRL/D & HRT/D & $\begin{array}{c}\text { Removal } \\
\text { efficiency }\end{array}$ & Country & Reference \\
\hline Domestic & Soil & P. karka & 1 & 9 & $\begin{array}{c}\text { COD 44\% } \\
\text { BOD 50\% } \\
\text { TSS 78\% } \\
\mathrm{NH}_{3} 49 \% \\
\mathrm{Po}_{4} 52 \% \\
\text { FC } 98 \%\end{array}$ & Pakistan & Mustafa, 2013 \\
\hline \multirow{2}{*}{ Domestic } & \multirow{2}{*}{ Gravel } & P. mauritianus & \multirow{2}{*}{2} & \multirow{2}{*}{12} & $\begin{array}{c}\text { BOD } 76 \% \\
\mathrm{NO}_{3} 58.1 \\
\mathrm{Po}_{4} 40.1 \\
\mathrm{FC} 93.9 \%\end{array}$ & \multirow{2}{*}{ Tanzania } & \multirow{2}{*}{ Mairi, 2012} \\
\hline & & Unplanted & & & $\begin{array}{c}\text { BOD } 48 \% \\
\mathrm{NH}_{3} 21.6 \% \\
\mathrm{Po}_{4} 5.2 \% \\
\text { FC } 58.7\end{array}$ & & \\
\hline \multirow[t]{2}{*}{ Raw domestic } & \multirow[t]{2}{*}{$\begin{array}{c}\text { Tezontile } \\
\text { rock }\end{array} \mid$} & Z. aethiopica & \multirow[t]{2}{*}{200} & \multirow[t]{2}{*}{3} & $\begin{array}{c}\text { COD 64\% } \\
\text { BOD 80.6 } \\
\text { TSS } 80.1 \\
\text { Org-N } \\
54.9 \% \\
\mathrm{NO}_{3} 53.6 \\
\mathrm{NH}_{4} 19.6 \% \\
\end{array}$ & \multirow[t]{2}{*}{ Mexico } & \multirow[t]{2}{*}{ Zurita et al., 2014} \\
\hline & & C. papyrus & & & $\begin{array}{l}\text { TP } 4.8 \% \\
\text { FC } 92 \%\end{array}$ & & \\
\hline \multirow{3}{*}{ Raw domestic } & \multirow{3}{*}{$\begin{array}{c}\text { Gravel } \\
(10-15 \\
\mathrm{mm})\end{array}$} & C. zizanoides & \multirow{3}{*}{40} & \multirow{3}{*}{0.92} & $\begin{array}{c}\text { TSS 90.2\% } \\
\text { TN 59.4\% } \\
\mathrm{NH}_{4} 51.8 \%\end{array}$ & \multirow{3}{*}{$\begin{array}{l}\text { San midi } \\
\text { Ganzaria }\end{array}$} & \multirow{3}{*}{$\begin{array}{c}\text { Maucieri et al., } \\
2014\end{array}$} \\
\hline & & M. giagnteus & & & $\begin{array}{l}\text { TSS } 81.2 \% \\
\text { TN } 45.7 \% \\
\mathrm{NH}_{4} 40 \%\end{array}$ & & \\
\hline & & P. australis & & & $\begin{array}{l}\text { TSS } 90.3 \% \\
\text { TN } 57.2 \% \\
\mathrm{NH}_{4} 54.3 \%\end{array}$ & & \\
\hline Domestic & $\begin{array}{c}\text { Gravel } \\
(5 \mathrm{~cm}) \\
\text { peat } \\
(35 \mathrm{~cm})\end{array}$ & P. australis & 0.27 & 22.6 & $\begin{array}{c}\text { BOD } 96.4 \\
\text { COD } 84.6 \\
\text { TSS } 94.8 \% \\
\text { TN } 79.5 \% \\
\mathrm{NH}_{4}-\mathrm{N} \\
98.8 \% \\
\text { TP } 83.7 \%\end{array}$ & Spain & $\begin{array}{l}\text { Andero-martiuer et } \\
\text { al., } 2016\end{array}$ \\
\hline
\end{tabular}

HLR = hydraulic loading rate, HRT = hydraulic retention time 


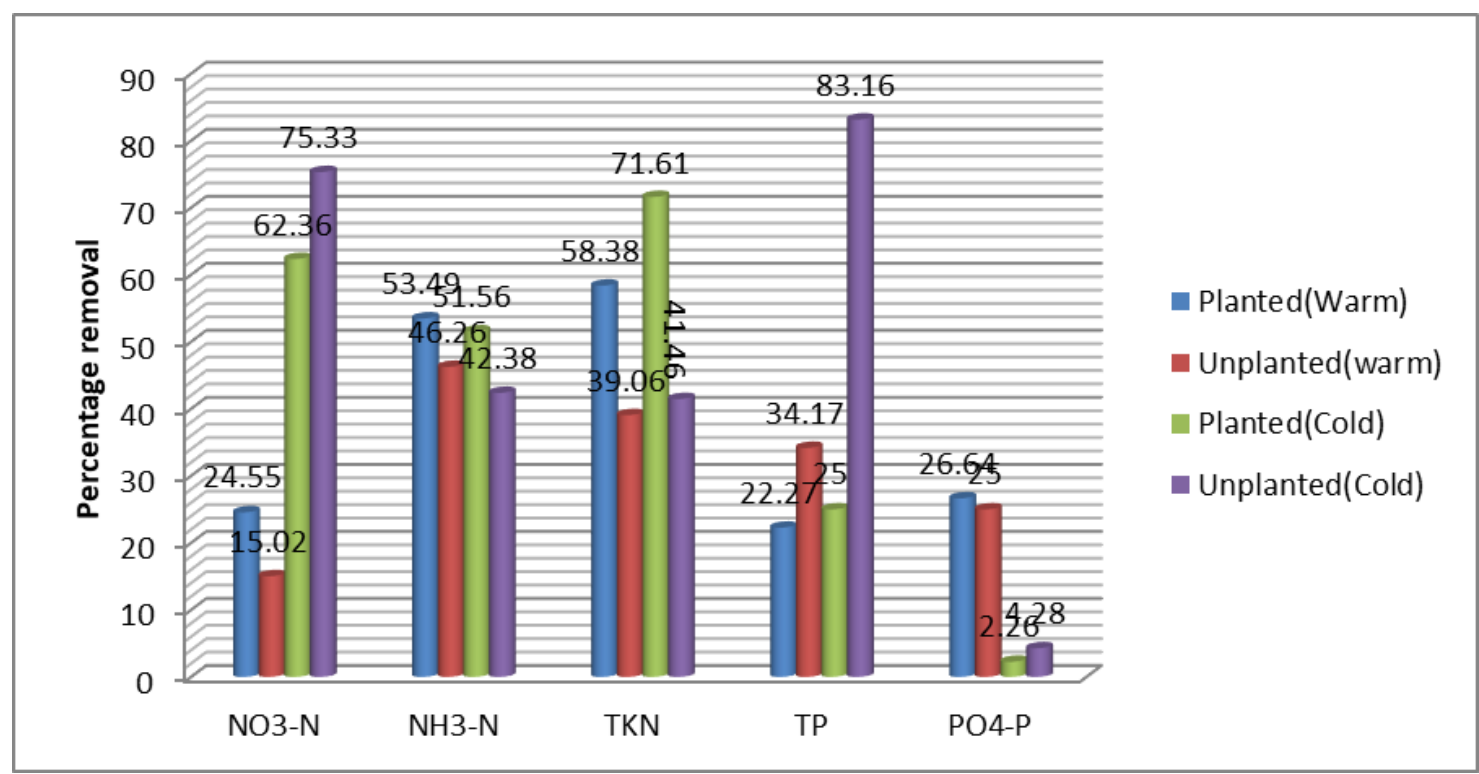

Figure 5. Effect of vegetation, climate and media on nutrient removal (Farzadkia et al., 2015)

The mean influent concentration of COD, TSS, NH4-N, NO3-N and PO4-P in January were $144,54,96,2.76$ and $3.62 \mathrm{mg} / \mathrm{L}$, respectively. The effluent concentrations after treating with constructed wetland were $64,8,62,1.69$ and $3.55 \mathrm{mg} / \mathrm{L}$, respectively. The mean percentage removal reductions for COD, TSS, NH4-N, NO3-N and PO4-P in this month were $55 \%, 85 \%, 35 \%, 39 \%$ and $2 \%$, respectively. The mean influent concentrations of these pollutants in February were 192, 38, 63, 2.91 and $4.12 \mathrm{mg} / \mathrm{L}$, respectively. The mean effluent concentrations were $64,4,28,2.33$ and $1.05 \mathrm{mg} / \mathrm{L}$, respectively. The mean percentage removal efficiency of the wetland was reached $66 \%$, $89 \%, 55 \%, 20 \%$, and $75 \%$ for COD, TSS, NH4-N, NO3-N and PO4-P, respectively. In hydrologic comparison in the constructed wetland indicated that the COD, TSS, NH4$\mathrm{N}, \mathrm{NO} 3-\mathrm{N}$ and PO4-P reductions were considerably greater in February compared to January. This was due to the lower HLR and greater HRT in February compared to January. The major mechanisms of TSS and COD removals in constructed wetlands are sedimentation, filtration and physical entrapment in the void pores of the sand and gravel medias. The higher HRT also allows for greater physical settling of suspended particles, which reduces the TSS and the higher residence time allows wetland plants to uptake nutrients effectively thereby decreasing the effluent concentrations (Tilak et al., 2016). The nitrogen content of Pistia stratiotes, Typha latifolia and Lemon grass in the subsurface flow constructed wetland were $37.4 \mathrm{~g} / \mathrm{kg}, 27.1 \mathrm{~g} / \mathrm{kg}$ and $15.8 \mathrm{~g} / \mathrm{kg}$, respectively.

The phosphorus accumulation capacity of these plant species were also $8.4 \mathrm{~g} / \mathrm{kg}$, $2.96 \mathrm{~g} / \mathrm{kg}$ and $2.29 \mathrm{~g} / \mathrm{kg}$, respectively for Pistia stratiotes, Typha latifolia and Lemon grass in the constructed wetland (Fig. 6) (Tilak et al., 2016). Subsurface flow constructed wetlands are good in utilizing pollutants in a symbiotic relation between aquatic plants and microorganisms in the media and the plant root system. Composite organic compounds confined in wastewater will be used up by plants as a nutrient, while the root structure of the aquatic plants will yield oxygen that can be used as energy or catalyst for a sequence of metabolic courses for heterotrophic aerobic microorganisms. Plants that are usually used include Cyperus alternifolus, Canna indica, 
Phragmites australis, Typha spp., Scirpus spp., etc. these plants reduce the concentration of BOD, COD, ammonia, nitrites, phosphorus and bacterial contaminants (Wijaya et al., 2016).

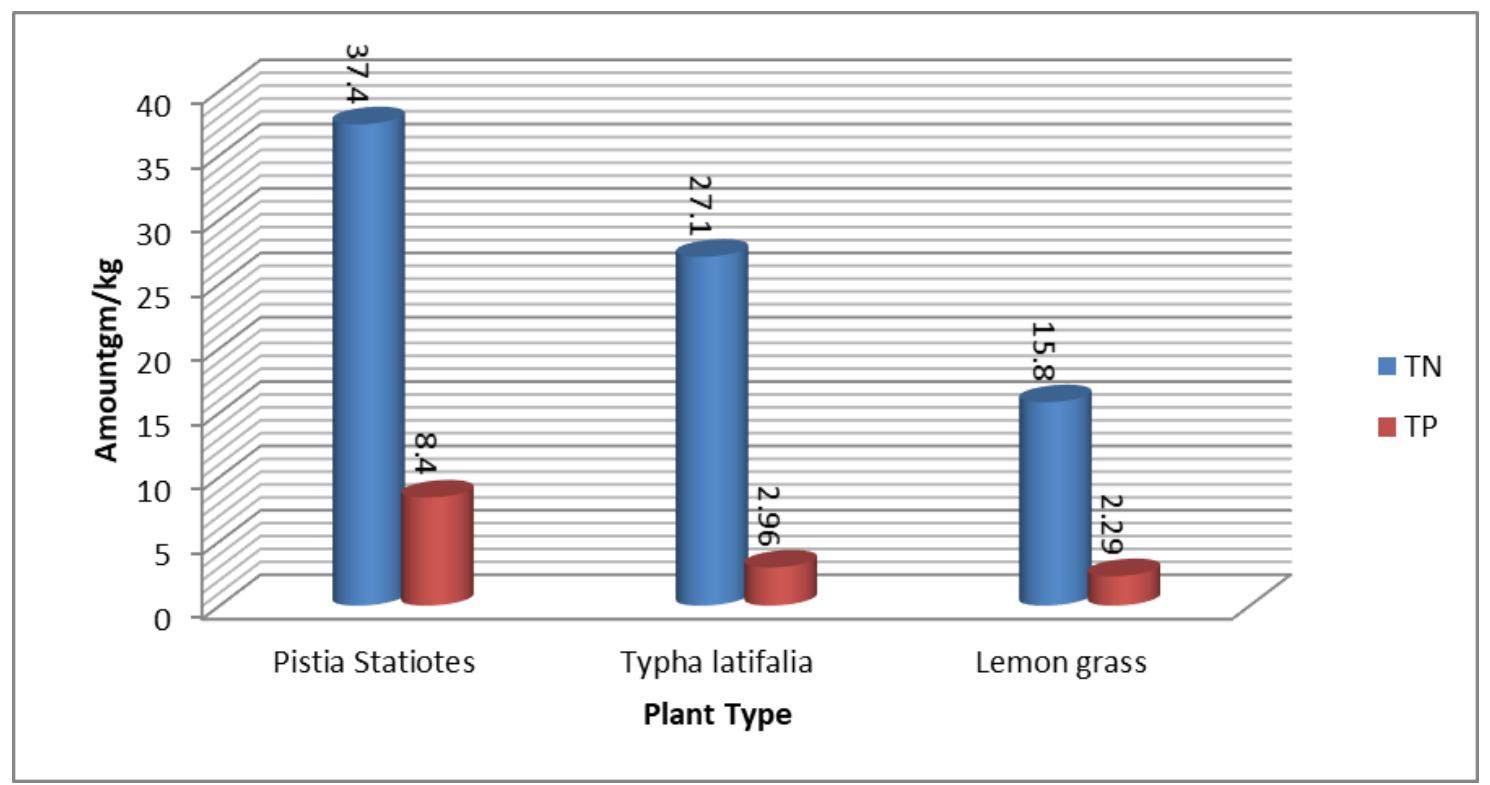

Figure 6. Nutrient accumulation in the wetland plants (Tilak et al., 2016)

The removal of nutrients from constructed wetlands are also dependent on the media types. The accumulation of total nitrogen and phosphorus in the constructed wetland media was also investigated by Tilak et al. (2016) as indicated in Figure 7.

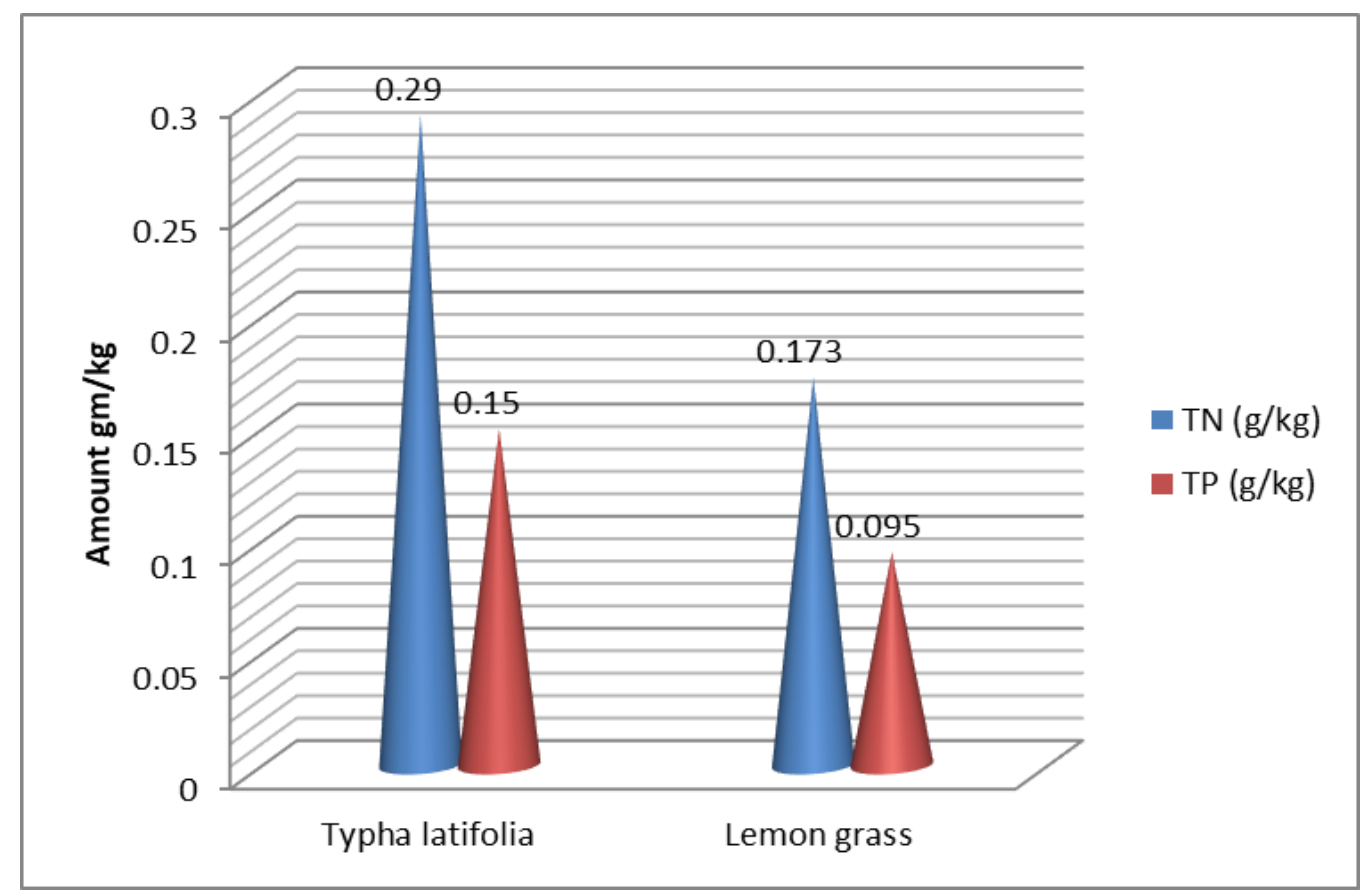

Figure 7. Nutrient accumulation in sand media (Tilak et al., 2016) 
The effect of vegetation on the organic matter removal was better than (i.e., 5 to $15 \%$ ) those of the unplanted. In general, the organic removal results suggest that control treatment influences wetland performance more than the type of macrophytes. The TSS removal efficiencies varied from 35 to $76 \%$ in both dry and nortes season. The organic matter (COD and BOD) removal showed similar pattern to that of TSS, which was varied from 36 to $68 \%$ and 28 to $69 \%$ for COD and BOD, respectively in the dry season, and whereas for the nortes season, they varied from 40 to $78 \%$ for COD and 49 to $74 \%$ for BOD. The nutrient removal efficiencies ranged from 47 to $66 \%$ and 59 to $79 \%$ for TN, 53 to $67 \%$ and 50 to $75 \%$ for $\mathrm{NH}_{4}+$ and 69 to $84 \%$ and 60 to $75 \%$ for $\mathrm{NO}_{3}$ - respectively for dry and nortes seasons. In general, the performance efficiency of the horizontal subsurface flow constructed wetland in organic matter, nutrient and pathogens were shown in Figures 8 and 9. The overall result clearly indicates that HRT is a key factor in the removal of a wide variety of contaminants (COD, BOD, TSS, TN, $\mathrm{NH}_{4}+\mathrm{NO}_{3}$ - and TP) in horizontal subsurface flow constructed wetland treating swine wastewater. According to the findings, the Typha latifolia and Eleocharis interstincta are the most suitable macrophyte species to be used for the treatment of piggery wastewater. In spite of the fact that high contaminant concentrations in wastewater may have masked the macrophytes; contributing to the overall treatment efficiency of HSSFCW, vegetated beds usually provide better effluent quality than unplanted beds (Puigagut et al., 2007).

The above graph indicates that the local macrophytes and natural substrate can perform successfully in the treatment of domestic wastewater. The results demonstrated that removals of organics (COD and BOD) are high in the horizontal subsurface flow constructed wetlands. The treatment efficiency of BOD nan COD ranged between 76 and $99.4 \%$ and 76 and $8.46 \%$, respectively except COD removal studied results in Thailand which varied between 42 and $83 \%$.

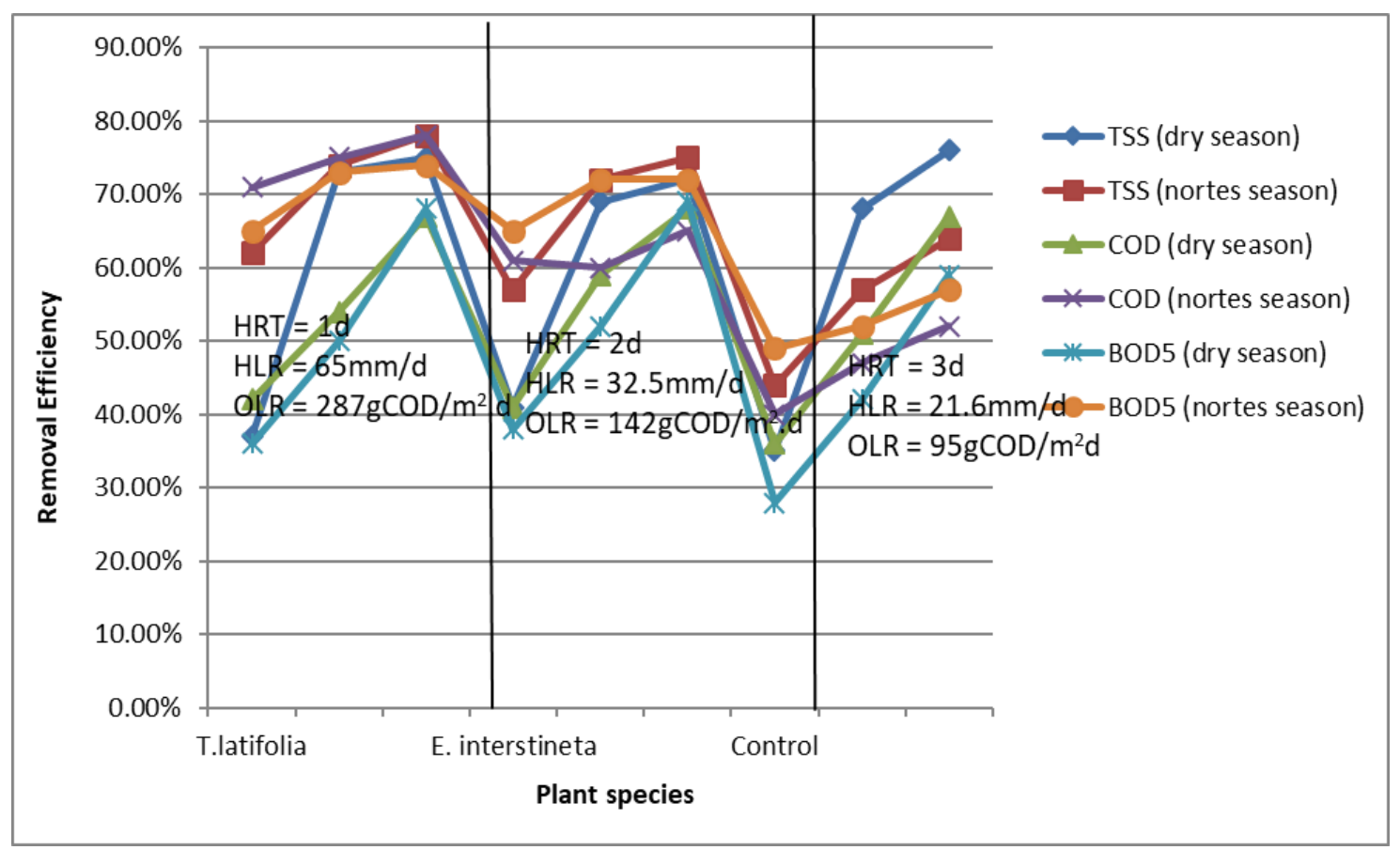

Figure 8. COD, BOD and TSS removal efficiency of HSSFCW at different seasons (Puigagut et al., 2007) 


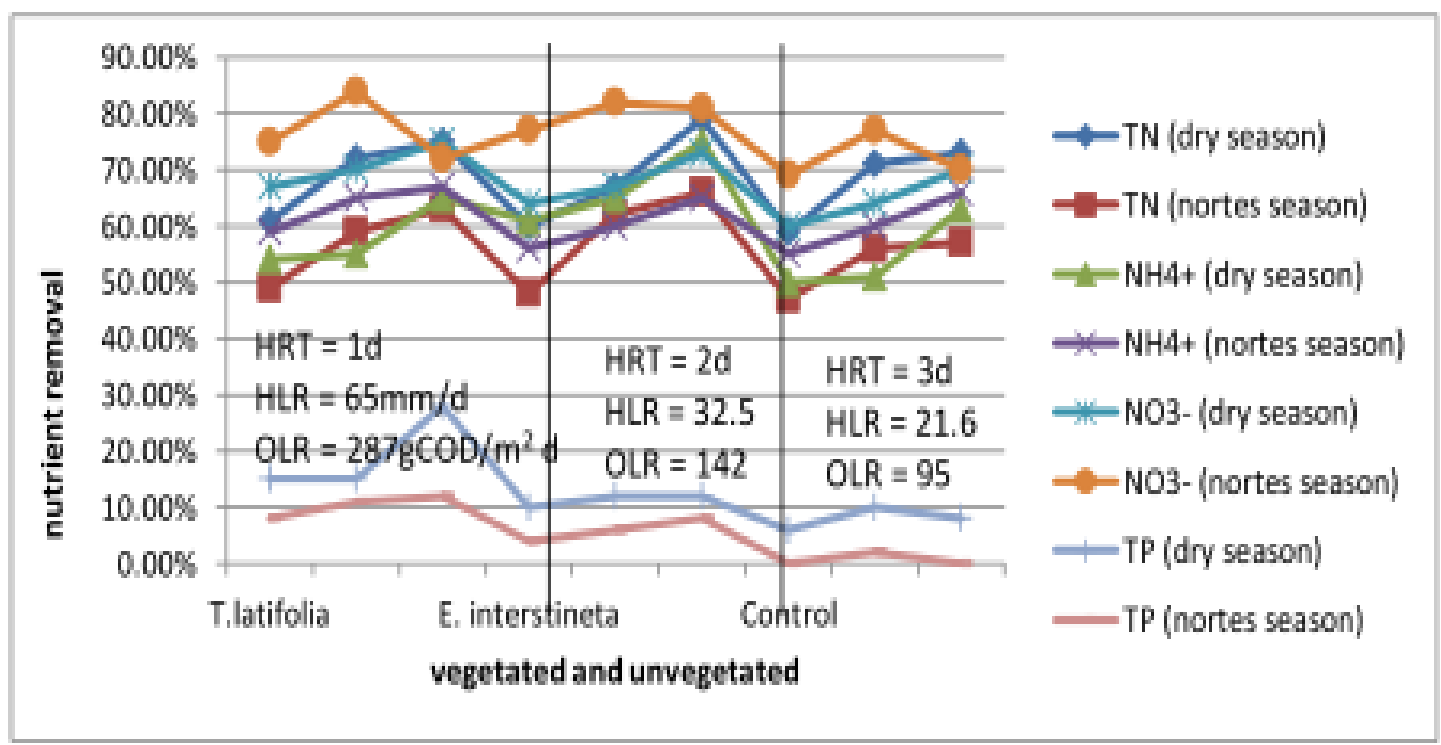

Figure 9. Influence of plant species and HRT on nutrient removal efficiency of HSSFCW

(Gonzalez et al., 2009)

\section{Performance efficiency of HSSFCW: a case in Ethiopia}

In Ethiopia, environmental degradation within and downstream of cities has multiple consequences for public health, in particular through the use of untreated wastewater in irrigated agriculture. Significant wastewater treatment efforts are done by Addis Ababa Water Supply and Sewerage Authority (AAWSSA), but it remained limited. Due to the combination of poor sanitation and undulating topography, almost all wastewaters generated in the city finds its way through a dense network of streams into Akaki Rivers (Little and Great Akaki rivers). Several factories also discharge their untreated effluents into the rivers. Wastewater collection and treatment are limited and treated wastewater is also discharged into the same river. Discharges from industry, domestic, and agricultures can cause an impact on environmental condition in river and coastal waters. Eutrophication is an accelerated growth of algae on higher forms of plant life caused by the enrichment of water by nutrients, especially compounds of nitrogen and/or phosphorus and inducing an undesirable disturbance to the balance of organisms present in the water and to the quality of the water concerned. Eutrophication of fresh water ecosystem is one of the most prevalent environmental problems responsible for water quality degradation on a world-wide scale. At present hardly any infrastructure is available for the effective treatment of sewage in developing countries.

Municipal sewerage and the extent of domestic and industrial wastewater treatment are inadequate in most urban situations. When there is a municipal sewerage network in place, the coverage is usually incomplete and the treatment level is insufficient. Even when treatment facilities exist, poor maintenance and operation often results in failing treatment processes, causing pollution of the effluent receiving surface waters. The risk of water borne diseases may actually increase in developing countries as a result of the introduction of a conventional sewerage scheme, since it is usually not accompanied by effective end-of-pipe treatment (UNEP/GPA, 2004). Untreated effluent contains high concentrations of salts, total suspended solids, chemical oxygen 
demand, nitrogen and phosphorous and toxic compounds, such as heavy metals and chlorinated organic compounds. Industrial effluents can seep into the aquifer and pollute groundwater or where it is discharged without proper treatment can affect the physico-chemical properties of the receiving water and consequently its biota (Kambole, 2003).

All this unregulated discharge of wastewater undermines biological diversity, natural resilience and has a significant impact on macro-invertebrates composition due to the water quality deterioration (Beyene et al., 2009). Addis Ababa City Rivers are highly affected by pollution of heavy metals, pathogens, organic compounds, synthetic chemicals, micro-plastics and nutrients (Aregawi, 2014). Study reports indicated that the city water bodies and surrounding agricultural soils are contaminated with heavy metals such as $\mathrm{Hg}, \mathrm{As}, \mathrm{Pb}, \mathrm{Sb}, \mathrm{Ni}, \mathrm{Sr}$, and $\mathrm{Cd}$ (Elias and Yohannes, 2017), which are extremely toxic even at low concentrations and cause gastrointestinal, skin, nerve damage, lung damage, cancer, nervous, immune system, and kidney damage, brain damage, liver damage, and etc. (Kassa, 2012). Beside these, water, soil and air pollution due to industrial and domestic waste discharges cause peculiar diseases. Study and literature report showed that most people found in Akaki Kality industrial zone are affected by peculiar diseases such as cough (76.5\%), diarrhea (58.8\%), typhoid $(51 \%)$, typhus (45.1\%), gastrointestinal (39.2\%), skin problem (29.4\%), asthma (33.3\%), and bronchitis (3.9\%) (Aregawi, 2014; Elias and Yohannes, 2017). This may be due to long term intake of food that contains high levels of heavy metals and pathogens, and contact with sediments containing heavy metals and pathogens, posing risks to human health (Itanna, 2002; Bekele, 2008) To protect water bodies from pollution, serious waste management implementation should be conducted. The main challenge mentioned by researchers is selecting the appropriate wastewater treatment techniques. Therefore, locally available effective pollution control systems are very important based on the country's economy. For this problem, constructed wetlands can be a good alternative options.

In Ethiopia, Terfie and Asfaw (2004) conducted a research on five pilot scale subsurface flows constructed wetlands; four units vegetated with Cyprus altenifolius, Typha domingensis, Phragmites karka and Borassus aethiopum and the fifth left as unvegetated (control). The performance efficiency of each cells in removing organic matter (COD \& BOD5), ammonium and total nitrogen including total chromium under the 5-day hydraulic retention time and hydraulic loading of $120 \mathrm{~L} /$ day showed promising results. The wastewater analysis indicated that COD reduction by $58-80 \%$ for an inlet organic loading rate (OLR) ranged from $2202-8100 \mathrm{mg} / \mathrm{L}$ and BOD5 reduction by $66-77 \%$ for an inlet OLR ranged from $650-1950 \mathrm{mg} / \mathrm{L}$. The removal of inorganic substances such as nitrates, sulfates, sulfides, total nitrogen and ammonianitrogen ranged from 30-57\%, 82-92.4\%, 53-82\%, 46-61\% and 64-82.5\%, respectively (Table 5). Similarly, Kassa and Mengistou (2014) tested pilot scale HSSFCWs efficiency in treating domestic wastewater in vegetated and unvegetated conditions at HLR and HRT of 7 day and 26 L/day HLR. The results showed that the nutrient removal efficiency of HSSFCW was significantly higher in the planted species than in the unplanted treatment system. The average removal efficiency of orthophosphate in the treatment beds was $84.05 \%$ for C. papyrus, $65.29 \%$ for P. Karaka and $50.20 \%$ for the unplanted. She proved that the average removal efficiency of planted cells was higher than unplanted due to the macrophytes role to accumulate high biomass and remove nutrients. 
Table 5. Pollutant removal efficiency of HSSFCW in Ethiopia

\begin{tabular}{|c|c|c|c|c|c|c|c|}
\hline $\begin{array}{c}\text { Types of } \\
\text { waste } \\
\text { water }\end{array}$ & Media type & Plant type & $\begin{array}{l}\text { HLR } \\
(\text { L/d) }\end{array}$ & $\begin{array}{l}\text { HRT } \\
\text { (day) }\end{array}$ & Removal efficiency (\%) & \begin{tabular}{|c|} 
Standards \\
(EEPA, \\
2000) \\
\end{tabular} & Reference \\
\hline \multirow{3}{*}{ Domestic } & \multirow{3}{*}{$\begin{array}{c}\text { Gravel } \\
(40-80 \mathrm{~mm}) \\
(20-30 \mathrm{~mm})\end{array}$} & C. papyrus & \multirow{3}{*}{17.7} & \multirow{3}{*}{2.16} & $\begin{array}{c}\mathrm{COD}=89.4 . \mathrm{BOD}=97.8 \\
\mathrm{TSS}=83.9 . \mathrm{TN}=53.9 \\
\mathrm{NH}_{4}=24.8 . \mathrm{NO}_{3}=82.4 \\
\mathrm{TP}=16.5 . \mathrm{PO}_{4}=22.3\end{array}$ & & \multirow{3}{*}{ Genet, 2007} \\
\hline & & C. alternifolia & & & $\begin{array}{c}\mathrm{COD}=87.3 . \mathrm{BOD}=97.7 \\
\mathrm{TSS}=82.3 . \mathrm{TN}=54.8 \\
\mathrm{NH}_{4}=24.6 . \mathrm{NO}_{3}=78 . \\
\mathrm{TP}=12.5 . \mathrm{PO}_{4}=16.2\end{array}$ & & \\
\hline & & P. canariensis & & & $\begin{array}{c}\mathrm{COD}=89.6 . \mathrm{BOD}=98.1 . \\
\mathrm{TSS}=83.2 . \mathrm{TN}=57 . \\
\mathrm{NH}_{4}=23 . \mathrm{NO}_{3}=81 . \\
\mathrm{TP}=18.1 . \mathrm{PO}_{4}=23.4\end{array}$ & & \\
\hline \multirow{5}{*}{ Tannery } & \multirow{5}{*}{$\begin{array}{c}\text { Clay } \\
(15 \mathrm{~cm} \text { and } \\
\text { gravel } 45 \mathrm{~cm})\end{array}$} & C. alternifolius & \multirow{5}{*}{120} & \multirow{5}{*}{5} & $\begin{array}{c}\mathrm{COD}=64.8 . \mathrm{BOD}=67.5 \\
\mathrm{TN}=46 . \mathrm{NH}_{4}=64.8\end{array}$ & \multirow{5}{*}{$\begin{array}{c}\mathrm{BOD}=80 \% \\
(200) \\
\mathrm{COD}=500 \\
\mathrm{TSS}=50 \% \\
\mathrm{NH}_{4}^{+}=30 \% \\
\mathrm{TN}=80 \% \\
(60 \%) \\
\mathrm{TP}=8 \% \\
(10)\end{array}$} & \multirow{5}{*}{$\begin{array}{l}\text { Terfie and } \\
\text { Asfaw, } \\
2014\end{array}$} \\
\hline & & T. domingensis & & & $\begin{aligned} \mathrm{COD} & =56.6 . \mathrm{BOD}=66 . \\
\mathrm{TN} & =46.7 . \mathrm{NH}_{4}=53\end{aligned}$ & & \\
\hline & & B. aerthiopium & & & $\begin{array}{c}\mathrm{COD}=58 \mathrm{BOD}=66 \mathrm{TN}=58 \\
\mathrm{NH}_{4}=80\end{array}$ & & \\
\hline & & P. karka & & & $\begin{array}{c}\mathrm{COD}=81 . \mathrm{BOD}=64 \\
\mathrm{TN}=61 . \mathrm{NH}_{4}=82.5\end{array}$ & & \\
\hline & & Unplanted & & & $\begin{array}{c}\mathrm{COD}=89.4 . \mathrm{BOD}=64 . \\
\mathrm{TN}=40.3 . \mathrm{NH}_{4}=62.7\end{array}$ & & \\
\hline \multirow{3}{*}{ Domestic } & \multirow{3}{*}{$\begin{array}{c}\text { Gravel } \\
(20-30 \mathrm{~mm})\end{array}$} & P. karka & \multirow{3}{*}{26} & \multirow{3}{*}{7} & $\begin{aligned} \mathrm{NO}_{3}-\mathrm{N} & =58.3 \% . \mathrm{PO}_{4-} \\
\mathrm{P} & =65.3 \%\end{aligned}$ & & \multirow{3}{*}{$\begin{array}{l}\text { Kassa and } \\
\text { Mengistu, } \\
2014\end{array}$} \\
\hline & & P. Cyprus & & & $\begin{aligned} \mathrm{NO}_{3}-\mathrm{N} & =56.4 \% . \mathrm{PO}_{4-} \\
\mathrm{P} & =50.2 \%\end{aligned}$ & & \\
\hline & & Unplanted & & & $\begin{aligned} \mathrm{NO}_{3}-\mathrm{N} & =36.1 \% . \mathrm{PO}_{4-} \\
\mathrm{P} & =50.2 \%\end{aligned}$ & & \\
\hline \multirow{2}{*}{ Domestic } & \multirow{2}{*}{$\begin{array}{c}\text { Gravel } \\
(8-16 \mathrm{~mm})\end{array}$} & P. australis & 18 & 6 & $\begin{array}{c}\text { BOD }_{5}=82 . \text { TSS }=78.3 . \\
\text { TN }=27\end{array}$ & & \multirow{2}{*}{$\begin{array}{l}\text { Ayano, } \\
2013\end{array}$} \\
\hline & & Unplanted & 18 & 6 & $\begin{array}{c}\mathrm{BOD}_{5}=82 . \mathrm{TSS}=78.3 \\
\mathrm{TN}=27\end{array}$ & & \\
\hline
\end{tabular}

Jehovah Witnesses Branch Office (JWBO) full scale HSSFCW performance was evaluated by Birhanu (2007) and the result showed average removal efficiency of the constructed wetland system for BOD5, COD, TSS, ammonium, nitrate, total nitrogen, orthophosphate, total phosphorus, sulfate, sulfide and total coliform was $99.3 \%, 89 \%$, $85 \%, 28.1 \%, 64 \%, 61.5 \%, 28 \%, 22.7 \%, 77.3 \%, 99 \%$ and $94.5 \%$, respectively. The individual cells removal efficiency indicated that the wetland planted with Cyprus papyrus showed higher removal efficiency for nitrate (82.4\%), ammonium $(24.8 \%)$, total nitrogen $(54.8 \%)$, orthophosphate $(23.5 \%)$, and total suspended solids $(83.9 \%)$ as compared to the other wetland systems. In the same regard, wetland cells planted with Phoenix canariensis showed higher removal efficiency for total phosphorus (17\%), sulfide (99\%), BOD5 (98\%), COD (90\%) and total coliform (94\%). Whereas, the other wetland cells planted with Cyprus alternifolia showed higher removal efficiency only for sulfate ion $(82.2 \%)$. The performance efficiency results indicated that, this wetland system has excellent removal capability for BOD5, COD, TSS, sulfate, sulfide and total coliform bacteria. However, since the HRT of the constructed wetland system (2.16 
days), the nutrient (nitrogen and phosphorus) removal efficiency was low. The organic matter removal efficiency of JWBO CW investigated by Brhanu (2007) was similar to that of the study done in the USA: i.e., BOD5 (93\%) (USEPA, 1993); in Kenya: BOD5 (98\%), COD (96\%) and TSS (85\%) (Nyakango, 1999); in Northern Alabama: BOD5 (85\%) (Kathleen, 2000); and in Italy: COD (93\%) and TSS (81\%) (Pucci, 2000). The higher removal of the planted treatment beds may be due to a combined biochemical reaction mechanism favored by plants, substrates and microorganisms. The most important effects of the macrophytes in relation to the wastewater treatment processes are the physical effects of the plant tissues that give rise to filtration effect and provide surface area for attached microorganisms. In addition to this, the media and macrophytes roots in SSF may provide a greater number of small surfaces, pores, and crevices which create the opportunity for the availability of a vast number of organic matter utilizing microorganisms adapted to the aerobic and anaerobic environment of wetland ecosystems which facilitate the organic matter removal process of $\mathrm{CW}$ more effectively (USEPA, 1993; Michael, 2006). On the other hand, the effectiveness may be associated with the presence of easily biodegradable organic matters in domestic wastewater by biological decomposition process within a short HRT (Reddy, 1991). According to Ayano' (2013) demonstration on the performance efficiency of horizontal subsurface flow constructed wetland at deferent depth with the same media type (gravel, 8-16 mm), wetland area and different hydraulic loading rate of $18 \mathrm{~L} / \mathrm{m}^{2} /$ day and $36 \mathrm{~L} / \mathrm{m}^{2} /$ day for depths $25 \mathrm{~cm}$ and $50 \mathrm{~cm}$ in planted and unplanted conditions, showed no significant difference in removal of pollutants at the same HLR. The removal of BOD5 and TSS were not different between planted and unplanted beds. However, areal and volumetric rates for planted beds were significantly greater than the unplanted beds for TKN. Unplanted beds may be more anaerobic than planted beds to favor reducing bacteria. Garcia et al. (2004) reported that the removal of HSSFCW increased with decreasing depth and attributed high oxidation reduction potential which is responsible for increasing nitrification. The result showed that constructed wetlands are successful in removal of nutrients from domestic wastewater.

\section{Heavy metal removal efficiency of HSSFCW}

\section{The toxicity nature of most heavy metals}

Recently there has been an increase in the river pollution trend in Addis Ababa and other cities, due to the discharge of untreated wastewater from the industries and municipal wastes. Constructed wetlands have a good potential for the removal of heavy metals from wastewater (Sahu, 2014). According to Sahu report, the horizontal subsurface flow constructed wetland reduced the concentration of $\mathrm{Hg}, \mathrm{Cr}, \mathrm{Fe}$ and $\mathrm{Ni}$ from the initial concentrations by $43 \%, 54 \%, 46 \%$ and $49 \%$, respectively. The potential heavy metal remediation of HSSFCW planted with Phragmites australis was investigated by Bahre (2013) and achieved high removal efficiency of 99.33\%, 93.67\%, $89.24 \%, 96.14 \%$ and $98.33 \%$, respectively for $\mathrm{Fe}, \mathrm{Mn}, \mathrm{Pb}, \mathrm{Cu}$ and $\mathrm{Zn}$ at hydraulic loading rate of $22 \mathrm{~L} \mathrm{~d}^{-1}$ and hydraulic retention time of 28th days. In the same regard, the unplanted unit showed removal efficiency of $98.43 \%, 91.66 \%, 85.01 \%, 90.70 \%$ and $85.19 \%$ for $\mathrm{Fe}, \mathrm{Mn}, \mathrm{Pb}, \mathrm{Cu}$ and $\mathrm{Zn}$, respectively at the same conditions. The result indicates that uptake on roots for $\mathrm{Pb}$ and $\mathrm{Cu}$ was higher than the uptakes by plant leaves and stems. The soil media heavy metals accumulation also showed the highest adsorption capacity for the analyzed heavy metals from the planted and control systems. 
This demonstrates that horizontal subsurface flow constructed wetland planted with Phragmites australis and red ash gravel can remove heavy metals from leachate.

This result is similar to the reported metal removal efficiency of subsurface flow constructed planted with S globulosus and E. sexangulare in treating leachates, which were $81.33 \%$ and $94.19 \%$, respectively for $\mathrm{Cu}$ and $\mathrm{Pb}$; while $86.91 \%$ and $95.88 \%$ removal in E. sexangular, respectively for $\mathrm{Cu}$ and $\mathrm{Pb}$ (Mohamed and Baskar, 2018). This finding also agrees with the result of Refidah (2002) who reported the removal efficiency of surface flow constructed planted with S. sumantresisana in treating leachate; which was $89 \%, 90 \%$ and $89 \%$, respectively for Fe, $\mathrm{Zn}$ and $\mathrm{Mn}$. The analysis of results showed that up to $99.3 \%$ of chromium was reduced from tannery wastewater for an inlet average $\mathrm{Cr}$ loading rate of $40 \mathrm{mg} / \mathrm{L}$ (Amenu, 2015). Similar values were reported by Terfie and Assfaw (2014) of total chromium in HSSFCW beds. The plant parts analysis on the accumulation of chromium showed similar results, more $\mathrm{Cr}$ was accumulated in root parts of the plants than in the shoot. This indicates that constructed wetland is a cost effective and environmentally friendly treatment method in removal of not only organic maters, nutrients and pathogens, but also heavy metals, and hence it can be used as an alternative treatment method for developing countries (Table 6).

Table 6. Heavy metal removal efficiency of HSSFCW in Ethiopia

\begin{tabular}{|c|c|c|c|c|c|c|c|}
\hline $\begin{array}{l}\text { Types of } \\
\text { waste } \\
\text { water } \\
\end{array}$ & Media type & Plant type & $\begin{array}{l}\text { HLR } \\
(\mathbf{L} / \mathbf{d})\end{array}$ & $\begin{array}{l}\text { HRT } \\
\text { (day) }\end{array}$ & Removal efficiency (\%) & $\begin{array}{c}\text { Standards } \\
\text { (EEPA, } \\
\text { 2000) } \\
\end{array}$ & Reference \\
\hline \multirow{2}{*}{ Leachates } & \multirow{2}{*}{$\begin{array}{c}\text { Redish gravel } \\
(40-80 \mathrm{~mm}) \\
(15-25 \mathrm{~mm})\end{array}$} & P. australis & \multirow{2}{*}{22} & \multirow{2}{*}{28} & $\begin{array}{c}\mathrm{Fe}=99.33 . \mathrm{Mn}=93.6 \\
\mathrm{~Pb}=89.24 . \mathrm{Cu}=96.14 \\
\mathrm{Zn}=98.33\end{array}$ & & \multirow{2}{*}{ Bahre, 2008} \\
\hline & & Unplanted & & & $\begin{array}{c}\mathrm{Fe}=99.33 . \mathrm{Mn}=93.6 \\
\mathrm{~Pb}=\text { 89.24. } \mathrm{Cu}=96.14 \\
\mathrm{Zn}=98.33\end{array}$ & & \\
\hline \multirow{5}{*}{ Tannery } & \multirow{5}{*}{$\begin{array}{c}\text { Clay } \\
(15 \mathrm{~cm} \text { and } \\
\text { gravel } 45 \mathrm{~cm})\end{array}$} & C. alternifolius & \multirow{5}{*}{120} & \multirow{5}{*}{5} & $\mathrm{Cr}=35.84$ & \multirow{5}{*}{$\begin{array}{c}\mathrm{Pb}=0.5 \\
\mathrm{Ni}=2 \\
\mathrm{Cu}=2 \\
\mathrm{Hg}=0.001 \\
\mathrm{Zn}=5 \\
\mathrm{Cr}=2\end{array}$} & \multirow{5}{*}{$\begin{array}{c}\text { Terfie and } \\
\text { Asfaw, } 2014\end{array}$} \\
\hline & & T. domingensis & & & $\mathrm{Cr}=48.68$ & & \\
\hline & & B. aerthiopium & & & $\mathrm{Cr}=26.96$ & & \\
\hline & & P. karka & & & $\mathrm{Cr}=30.26$ & & \\
\hline & & Unplanted & & & $\begin{array}{c}\mathrm{Cr}=59.6 \text { for clay, } 38.15 \text { for } \\
\text { Gravel }\end{array}$ & & \\
\hline Syntatic & - & - & 48.6 & 9 & $\begin{aligned} \mathrm{Cr} & =51 . \mathrm{Ni}=47 \\
\mathrm{Fe} & =45 . \mathrm{Hg}=43\end{aligned}$ & & Sahu, 2014 \\
\hline
\end{tabular}

\section{Heavy metals in plant tissues and substrate media}

The probable recognized biological processes for metal removal in wetlands are plant uptake and adsorption on the substrate media. The $\mathrm{Pb}$ and $\mathrm{Cu}$ uptake ability of $\mathrm{P}$. australis by its roots may be due to the localized properties of the root, mainly predominated rhizofiltration mechanisms to accumulate heavy metals (Zhu et al., 1999). Similarly, Kadlec and Wallace (2009) reported that plants can accumulate higher concentrations of metals in their roots. This may be due to the slow mobility of metal transport from the root to shoot. In the same case, substrate media is also one of the important factors for the removal of heavy metals. Figures 10 and 11 indicate the role of substrate media for $\mathrm{Pb}$ and $\mathrm{Cu}$ removal from leachate. However, the retention time and the type of media have an effect on the treatment of wetland (Knox et al., 2004). Since media provides a viable 
condition for maximum removal of pollutants, due to its diverse treatment mechanisms including sedimentation, adsorption, precipitation and microbial interaction (USEPA, 1993). In general, the control HSSFCW showed the higher removal efficiency of $\mathrm{Pb}$ and $\mathrm{Cu}$ than the planted wetland. Similar finding was observed in the removal of chromium from tannery wastewater (Terfie and Assfaw, 2014). This may be due to chemical precipitation and sorption of metals on substrate media.

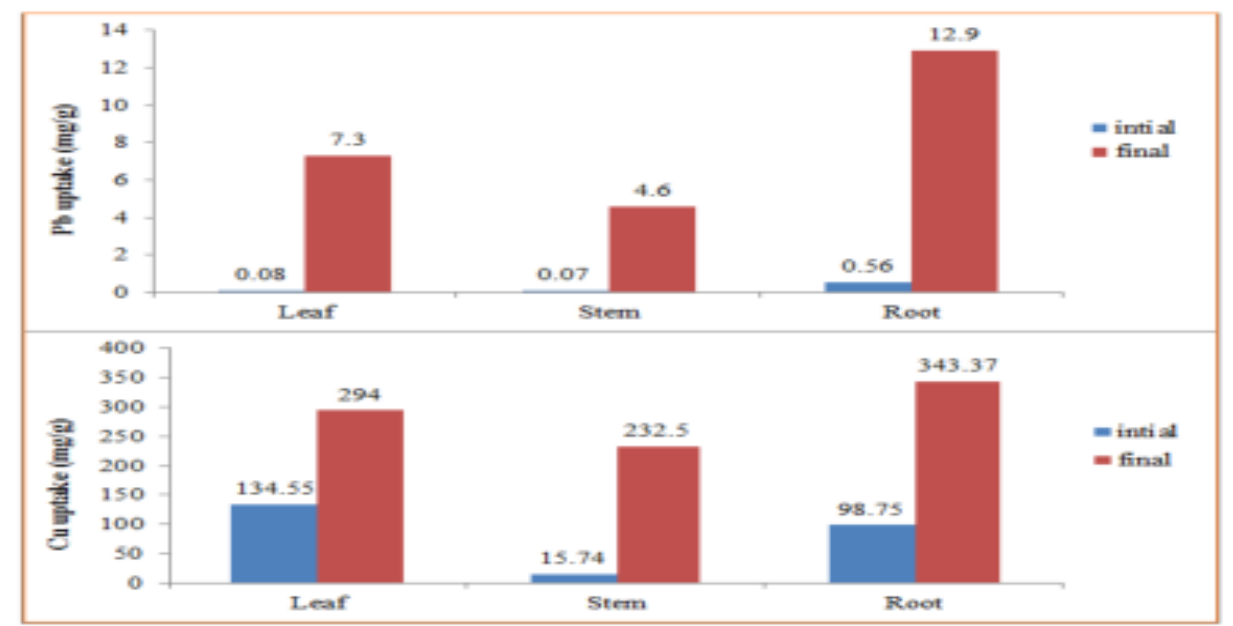

Figure 10. $P b$ and $C u$ uptake of different parts of P. australis in CW (Knox et al., 2004)

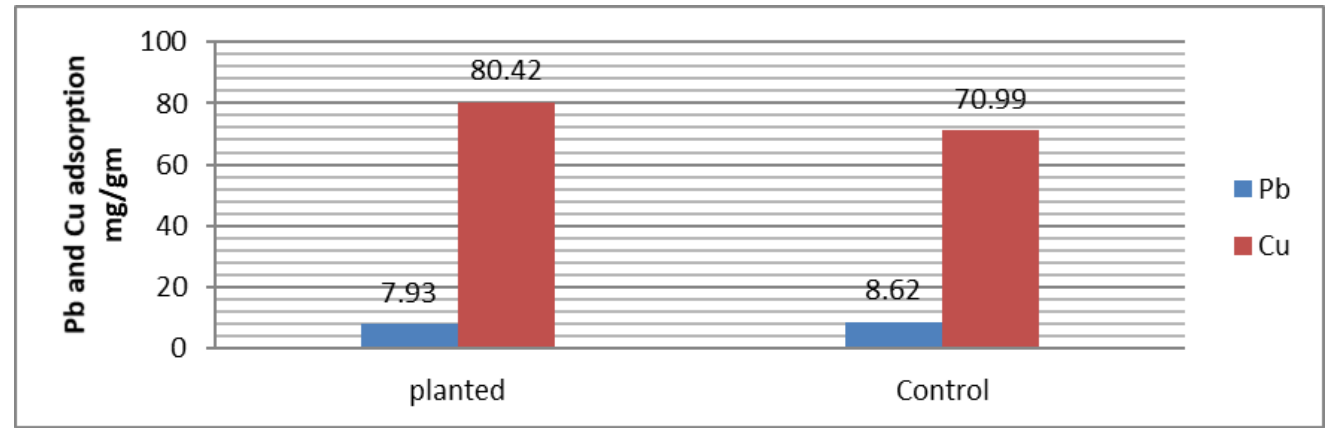

Figure 11. $\mathrm{Pb}$ and $\mathrm{Cu}$ adsorption in planted and control $\mathrm{CW}$ beds (substrate media, red ash gravel) (Knox et al., 2004)

Terfie and Assfaw (2014) investigation data indicates clearly the fate of total chromium in the horizontal subsurface flow constructed wetland (Fig. 12a). Whereas Kassa and Mengistou (2014) investigated data on the fate of total phosphorus is under question mark, where the fate of TP is in a constructed wetland (Fig. 12b).

However, the removal efficiency of heavy metals is dependent on the HRT, flow rate (Q) and pH. Sahu (2014) determined the effect of HRT on the reduction of different heavy metals. The treatment efficiency was observed increased as HRT increases from 1 to 7 days at a flow rate of $8 \mathrm{~cm}^{3} / \mathrm{min}$ (Fig. 13). As Fig. 13 showed the maximum removal of 54\%, 49\%, $46 \%$ and $43 \%$ were obtained respectively for $\mathrm{Cr}, \mathrm{Ni}, \mathrm{Fe}$ and $\mathrm{Hg}$ at 7 days HRT. The effect of HRT on the removal of heavy metals was also determined by Bahre (2013) and presented in Figure 14. 


$$
-1073 \text { - }
$$

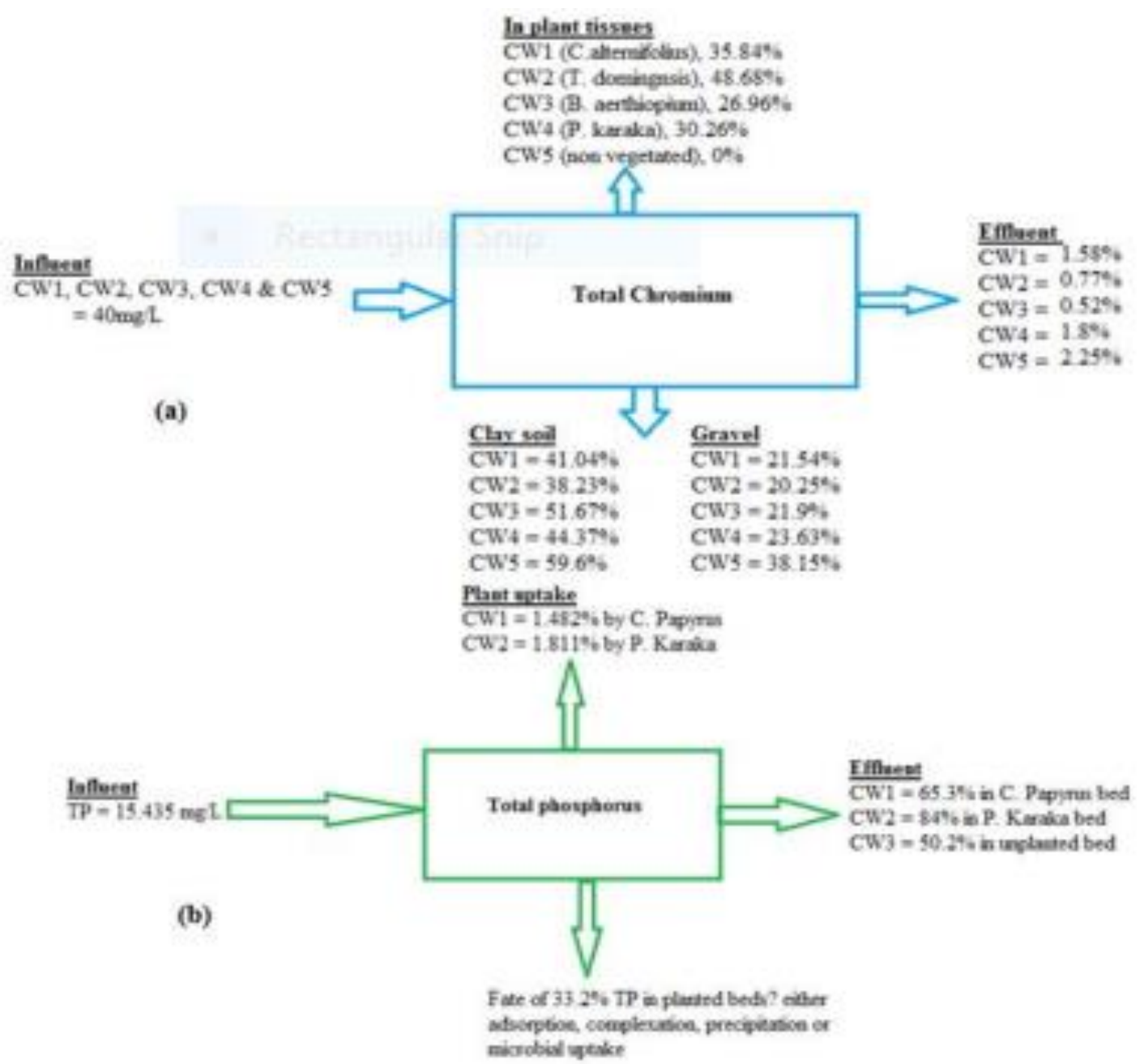

Figure 12. a Mass balance of chromium. $\boldsymbol{b}$ Mass balance of TP in HSSFCWs (Kassa and Mengistou, 2014)

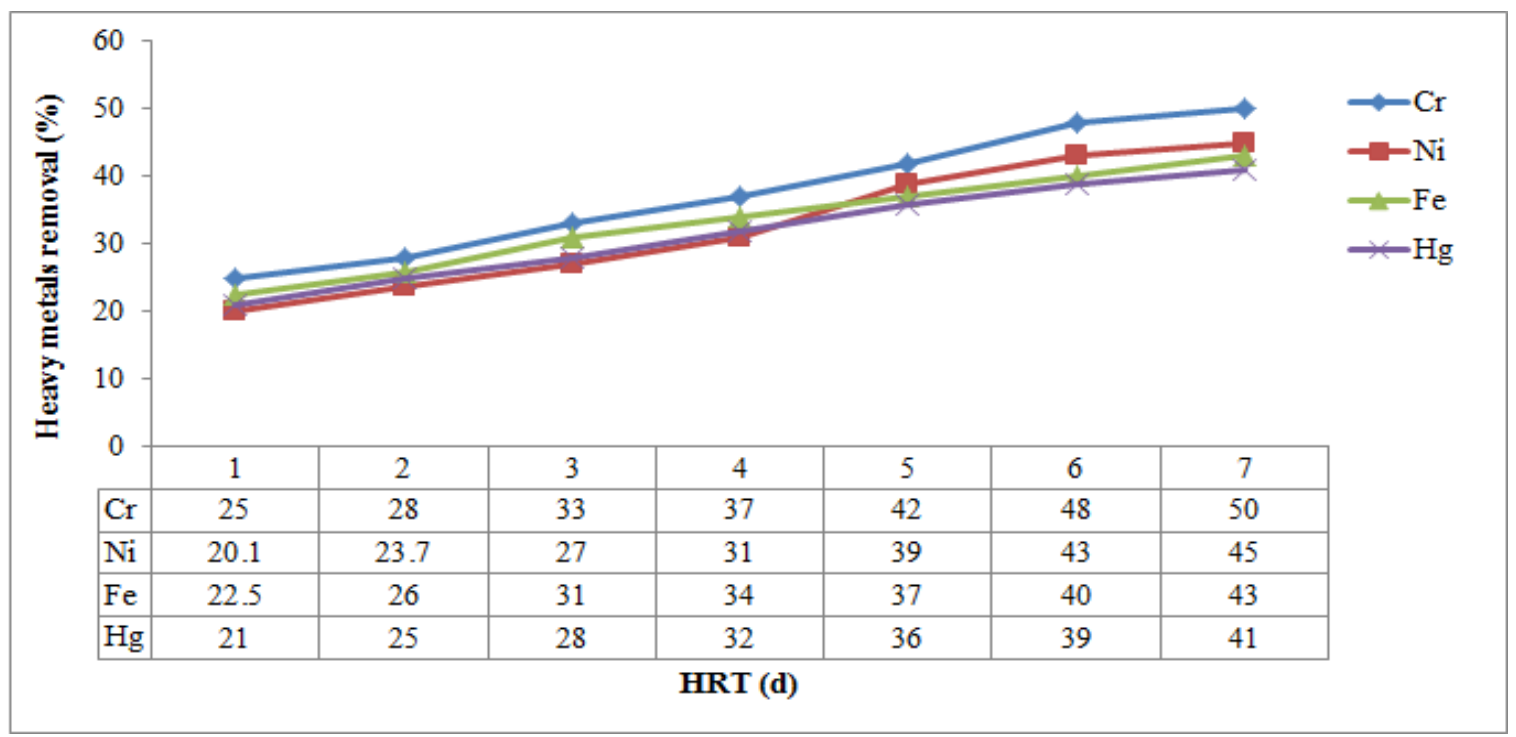

Figure 13. Effect of HRT on heavy metals removal from HSSFCW (Bahre, 2013) 


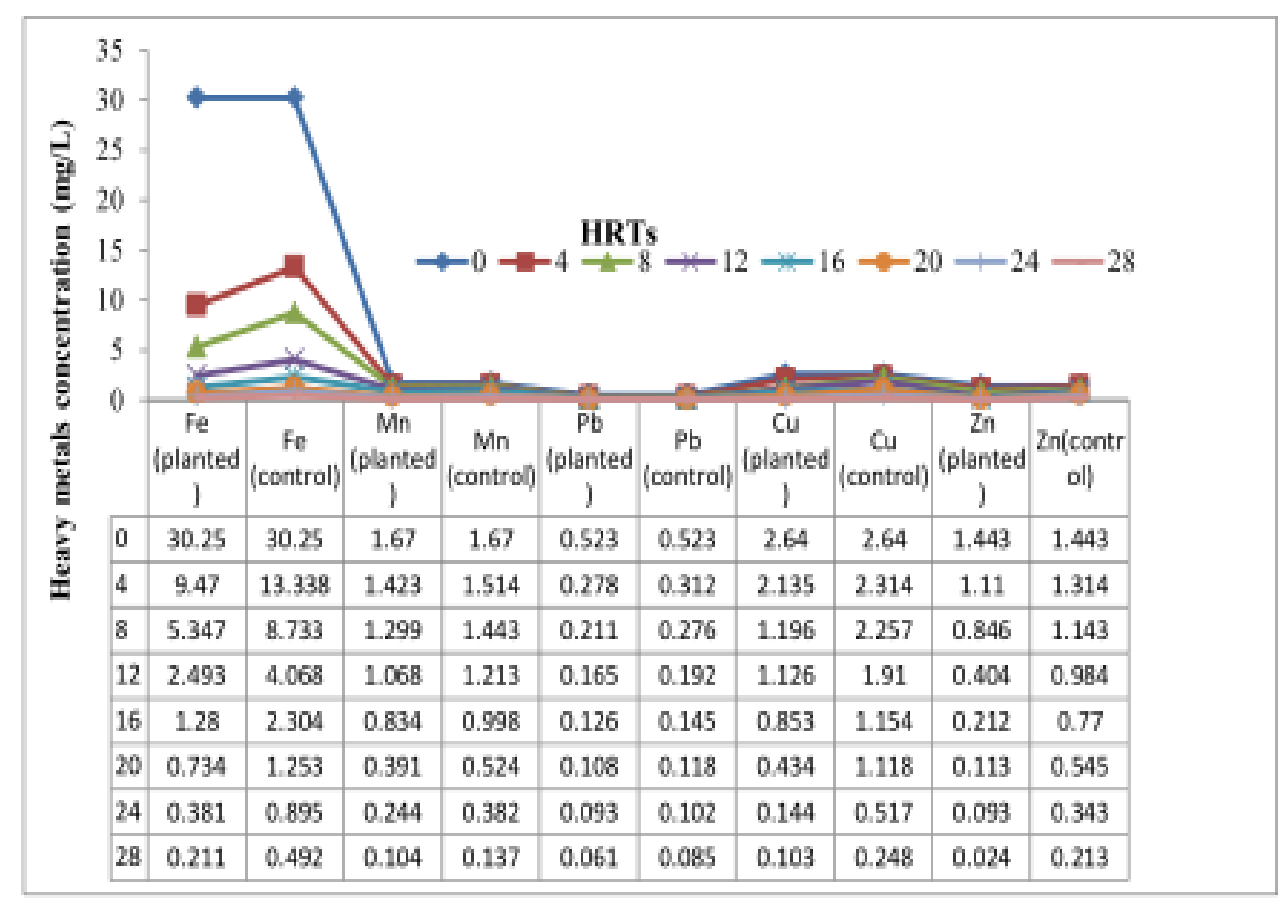

Figure 14. Effect of vegetation and HRT on the removal efficiency of heavy metals (Bahre, 2013)

\section{Factors affecting the performance efficiency of constructed wetlands}

\section{Vegetation and HRT}

The TSS removal efficiency of planted and unplanted constructed wetland at different HRT was significantly different. The initial TSS concentration was $106 \mathrm{mg} / \mathrm{L}$. Some while after treatment under $\mathrm{CW}$ were reduced to 35.4 and $19.7 \mathrm{mg} / \mathrm{L}$ at 2 and 4 days HRT with a removal efficiency of $66.7 \%$ and $81.5 \%$, respectively in the vegetated one. Whereas, for the unplanted CW, TSS were reduced to 62.3 and $49.8 \mathrm{mg} / \mathrm{L}$ for 2 and 4 days HRT with total removal efficiency of $41.5 \%$ and $53.2 \%$, respectively. The planted $\mathrm{CW}$ had higher results in TSS removal than the unplanted one (Fig. 15). Increase of HRT resulted in better TSS removal efficiency even for the non-vegetated CW. The efficiency of BOD5 removal was $52 \%$ and $73.4 \%$ at HRT of 2 and 4 days in the planted beds. Constructed wetland without plantation removed only 20-35\% BOD5 from the influent.

Constructed wetland planted with Canna indica L. gave higher $\mathrm{BOD}_{5}$ removal efficiency than non-vegetated CW. The BOD5 removal also increased at higher HRT (i.e., almost half BOD5 removed at 4 days HRT) than shorter HRT (i.e. 2 days HRT). TKN removal in the vegetated $\mathrm{CW}$ also gave the maximum removal efficiency compared to the non-vegetated $\mathrm{CW}$. This removal efficiency of TKN may be associated with addition of plant activity. CW planted with Canna indica L. removed TKN for $45.3 \%$ for 2 days HRT and $69.6 \%$ for 4 days HRT. TKN removal efficiency had increased at increasing HRT (Panrare et al., 2015). This TKN removal of the CW technique may be due to volatilization, plant uptake and bacterial assimilation (Vymazal, 2007). The vegetated $\mathrm{CW}$ at $4 \mathrm{HRT}$ also gave the highest phosphate removal efficiency (77.7\%). This phosphate removal in CW could be normally by plant and bacterial uptake, adsorption at the media and sedimentation. The effect of vegetation and HRT on the performance efficiency of constructed wetland is indicated in Figure 15. 


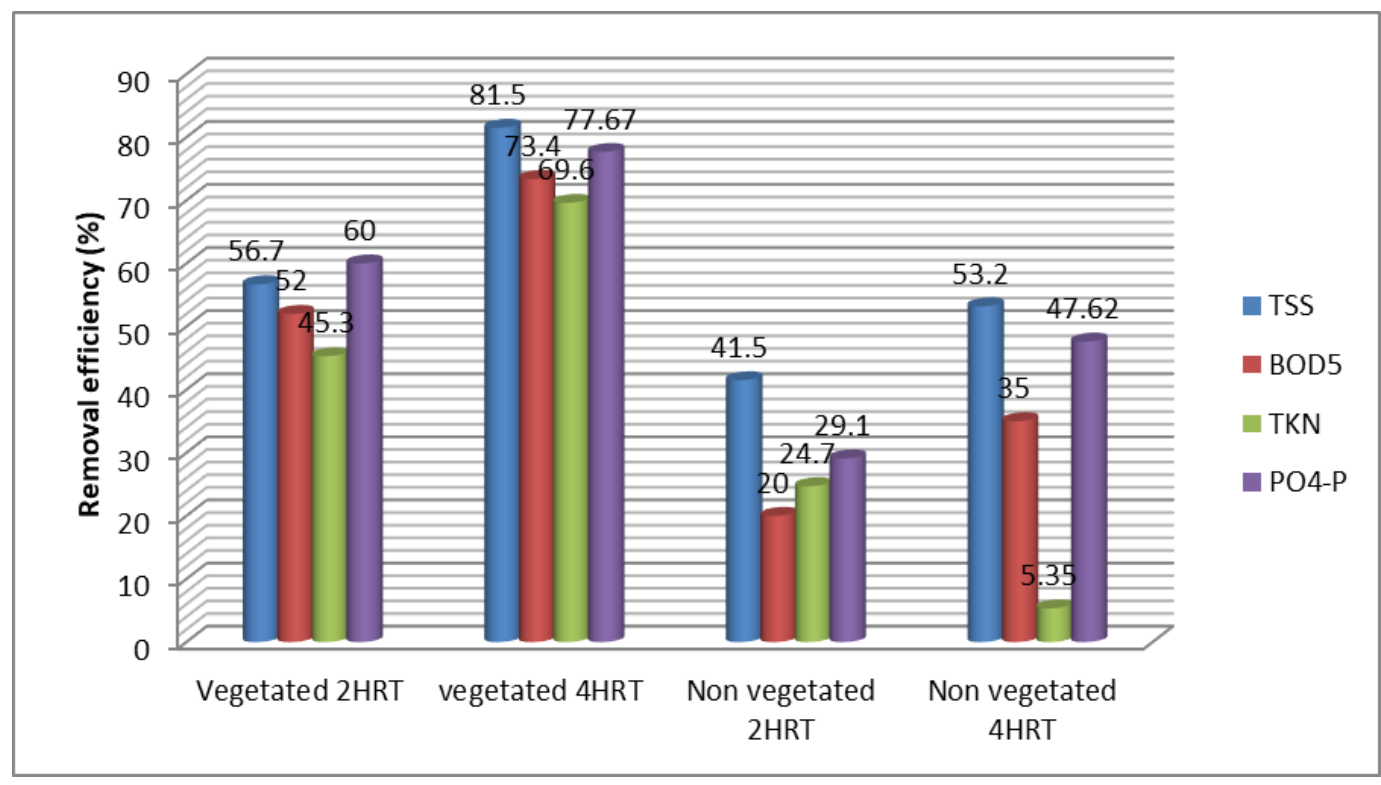

Figure 15. Effect of vegetation and HRT on pollutant removal efficiency of CW

\section{Plant species}

Plants used in constructed wetlands play a major role in absorbing nutrients from wastewater. Some of the most important plant species with nutrient absorbing ability is summarized in Table 7.

Table 7. Nutrient absorption capacity of macrophytes (Brix, 1994)

\begin{tabular}{c|c|c|c|c|c|c|c}
\hline \multicolumn{2}{c|}{ Media type } & $\begin{array}{c}\text { Cyperus } \\
\text { alternifolus }\end{array}$ & $\begin{array}{c}\text { Typha } \\
\text { latifolia }\end{array}$ & $\begin{array}{c}\text { Eichornia } \\
\text { crassipes }\end{array}$ & $\begin{array}{c}\text { Pistia } \\
\text { stratoites }\end{array}$ & $\begin{array}{c}\text { Potamogeton } \\
\text { pectinatus }\end{array}$ & $\begin{array}{c}\text { Certophylum } \\
\text { demersum }\end{array}$ \\
\hline $\begin{array}{c}\text { Absorption } \\
\text { capacity } \\
\mathrm{kg} / \mathrm{ha} / \mathrm{h}\end{array}$ & $\mathrm{N}$ & 1100 & 1000 & 2400 & 900 & 500 & 100 \\
\cline { 2 - 8 } & $\mathrm{P}$ & 50 & 180 & 350 & 40 & 40 & 10 \\
\hline
\end{tabular}

\section{Media type}

The level of permeability and hydraulic conductivity of the media is very influential on the retention time of wastewater, in which the retention time is enough to give a chance to contact between microorganisms in wastewater and oxygen released by plant roots. The main function of the media in the constructed wetland is to provide places for plants to grow, microbial attachment for pollutant transformation process, and nutrient absorption (Dadan, 2016). The performance of subsurface flow constructed wetland based treatment can be shown in Table 8.

\section{Microorganisms}

Preferably heterotrophic aerobic microorganisms are present due to faster processing ability than anaerobic types. The oxygen content in the media will be supplied by plant roots, which is a byproduct of the process of photosynthesis of plants with the help of sunlight (Dadan et al., 2016). 


\section{Temperature}

The temperature of wastewater affects the activity of microorganisms and plants, furthermore it will affect the performance of processing (Dadan et al., 2016).

Table 8. Performance of SSFCW media (Khiatuddin, 2003)

\begin{tabular}{c|c|c|c|c|c}
\hline \multicolumn{2}{c|}{ Media type } & Gravel & Soil & Sand & Clay \\
\hline $\begin{array}{c}\text { Percentage of } \\
\text { removal }\end{array}$ & BOD & $55-96$ & $62 \_85$ & 96 & 92 \\
efficiency (\%) & SS & $51 \_98$ & $49 \_85$ & 94 & 91 \\
\hline
\end{tabular}

\section{Constructed wetland as climate change mitigation}

Constructed wetlands are increasingly widespread for wastewater treatment in small communities and households where in addition to the fundamental purifying function, they also have decorative function that imposes the choice of plants characterized by high functional, amenity, and aesthetic values (Ghermandi et al., 2010). Constructed wetlands carbon cycles contribute to the global greenhouse gases (GHGs) balance through their $\mathrm{CO}_{2}$ and $\mathrm{CH}_{4}$ emissions. In particular, they can act as $\mathrm{CO}_{2}$ sinks by photosynthetic $\mathrm{CO}_{2}$ assimilation from the atmosphere or as a source of $\mathrm{CO}_{2}$ through bed respiration (Barbera et al., 2009) and organic matter decomposition (Brix et al., 2001). The rate of carbon decomposition in constructed wetlands depends on the redox chemistry of the soil, the bioavailability of organic carbon and temperature. For example, in summer season, oxygen diffusion to the topsoil can reduce methanogenesis and stimulate methane oxidation (Grünfeld and Brix, 1999). However, an increase in temperature can decrease dissolved oxygen in deeper subsoil and enhance methane production. All biochemical reactions increase as temperature increases $\mathrm{C}$ and $\mathrm{N}$ turnover in constructed wetlands causing high variations in $\mathrm{GHG}$ emissions in different regions. Due to this more data and investigation are needed on constructed wetland types for better extrapolation of GHG emissions. Hence, organizing more information on nutrient removal efficiency and GHG emissions across $\mathrm{CW}$ in different $\mathrm{CW}$ types is necessary for better management. Emissions of GHG in CWs can vary across CW types, e.g., surface flow or subsurface flow (Tables 9 and 10$)$.

Generally, methane emissions are higher in surface flow CWs (SFCWs) than subsurface flow constructed wetlands (Table 9), but may vary with season. Nitrous oxide and carbon dioxide emissions are higher in VSSFCWs than in HSSFCWs and SFCWs. Aquatic plants play an important role in GHG production and transport to the atmosphere by releasing GHG through their interconnected internal gas lacunas. Emergent plants can transport atmospheric oxygen to the rooting zone and contribute to increase the $\mathrm{N}_{2} \mathrm{O}$ and $\mathrm{CO}_{2}$ production and methane consumption (Brix, 1989). Release of low molecular weight organic matter that is labile in nature is more likely to produce GHGs than stable forms. A fluctuating water table in CWs has significant impacts on GHG dynamics (Mander, 2011). In aerobic and anaerobic conditions, incomplete nitrification and denitrification increase $\mathrm{N}_{2} \mathrm{O}$ emissions (Healy et al., 2007). In general, assessment of GHG emissions in various types of CWs which are vegetated or unvegetated is necessary in the light of the national and global GHG budgets. 
Table 9. Nitrous oxide emission from various CW types $\left(\mathrm{m} \mathrm{g} \mathrm{m}^{-2} d^{-1}\right)$

\begin{tabular}{c|c|c|c}
\hline CW type & Type of WW & $\begin{array}{c}\mathbf{N}_{2} \mathbf{O} \text { emission } \\
\left(\mathbf{m ~ g ~ m}^{-2} \mathbf{d}^{-\mathbf{1}}\right)\end{array}$ & Reference \\
\hline Surface flow & Municipal & 2 & Johansson, 2003 \\
SF & Dairy & 16.8 & Van der Zaag, 2010 \\
SF & Municipal & 0.01 & Søvik, 2006 \\
SF & Agri runoff & 0.4 & Søvik, 2006 \\
SF & Municipal & 4 & Søvik, 2006 \\
All SF & & 4.642 & Mander, 2005 \\
Horizontal sub surface flow & Domestic & 8.6 & Søvik, 2006 \\
HSSF & Municipal & 7.1 & Liu et al., 2009 \\
HSSF & Domestic & 0.17 & Van der Zaag, 2010) \\
HSSF & Dairy & 9.5 & Mander, 2011 \\
HSSF & Domestic & 0.17 & Mander, 2008 \\
All HSSF & & 5.108 & Mander, 2005 \\
\hline Vertical sub surface flow & Domestic & 4.6 & Mander, 2011 \\
VSSF & Domestic & 11 & Gui et al., 2007 \\
VSSF & Domestic & 1.44 & Søvik, 2006 \\
VSSF & Domestic & 0.005 & \\
VSSF & Municipal & 15 & \\
All VSSF & & 6.409 &
\end{tabular}

Table 10. Carbon dioxide and methane emission from various CW types $\left(m g m^{-2} d^{-1}\right)$

\begin{tabular}{c|c|c|c|c}
\hline CW type & Type of WW & $\mathbf{C O}_{2}$ emission & $\mathbf{C H}_{\mathbf{4}}$ emission & Reference \\
\hline SF & Dairy & 4250 & 223 & Van der Zaag, 2010 \\
SF & Municipal & 1200 & 29 & Søvik, 2006 \\
SF & Agri runoff & 3200 & 350 & Søvik, 2006 \\
SF & Municipal & 1400 & 72 & Søvik, 2006 \\
ALL SF & & 2512.5 & 168.5 & \\
\hline HSSF & Domestic & 5.33 & 0.001 & Garcia, 2005 \\
HSSF & Dairy & 3475 & 118 & Van der Zaag, 2010 \\
HSSF & Domestic & 600 & 0.48 & Mander, 2011 \\
HSSF & Municipal & 3800 & 340 & Søvik, 2006 \\
ALL HSSF & & 1970.1 & 114.6 & \\
\hline VSSF & Municipal & 2662 & 33.5 & Mander, 2008 \\
VSSF & Domestic & 1080 & 3.36 & Mander, 2011 \\
VSSF & Municipal & 8400 & 110 & Søvik, 2006 \\
VSSF & Municipal & 22000 & 140 & Søvik, 2006 \\
ALL VSSF & & 8535.5 & 71.72 & \\
\hline
\end{tabular}

Even if constructed wetlands are contributors of GHG, on the other hand, constructed wetlands present an important opportunity for carbon sequestration and greenhouse gas offsets by virtue of their potential for restoration using known and innovative land management methods. Because constructed wetlands are inherently highly productive and accumulate large below-ground stocks of organic carbon. Wetlands are major carbon sinks. While vegetation traps atmospheric carbon dioxide in wetlands and other ecosystems alike, the net-sink of wetlands is attributed to low decomposition rates in anaerobic zones. Recently, constructed wetlands used for wastewater treatment and 
protecting wetland bodies clearly represent an immediate and large opportunity for enhancing carbon sequestration (Kanungo et al., 2017). The percentage of organic carbon (OC\%) content of the 15 emergent macrophytes varied between 34.97 to $50.92,34.98$ to $52.04,34.96$ to 52.01 and 34.91 to 50.94. similarly, biomass $\left(\mathrm{g} / \mathrm{m}^{2}\right)$ ranged from 104 to 687, 16 to 1382,141 to 1493 and 122 to 635 . The carbon sequestration potential (CSP) was determined by multiplying the $\mathrm{OC}$ in per gram of dry weight to the biomass of that species (Wang et al., 2011) and the total CSP of all the emergent macrophytes was obtained by the summation of individual CSP of all species. Based on this calculation, the highest CSP was recorded for Typha latifolia followed by Phragmites australis and the lowest for Carexsp. (Fig. 16) which exhibited from the highest carbon content of 53.62\% which was greater than the $44 \%$ value reported by Wang et al. (2011) for Typha orientalis.

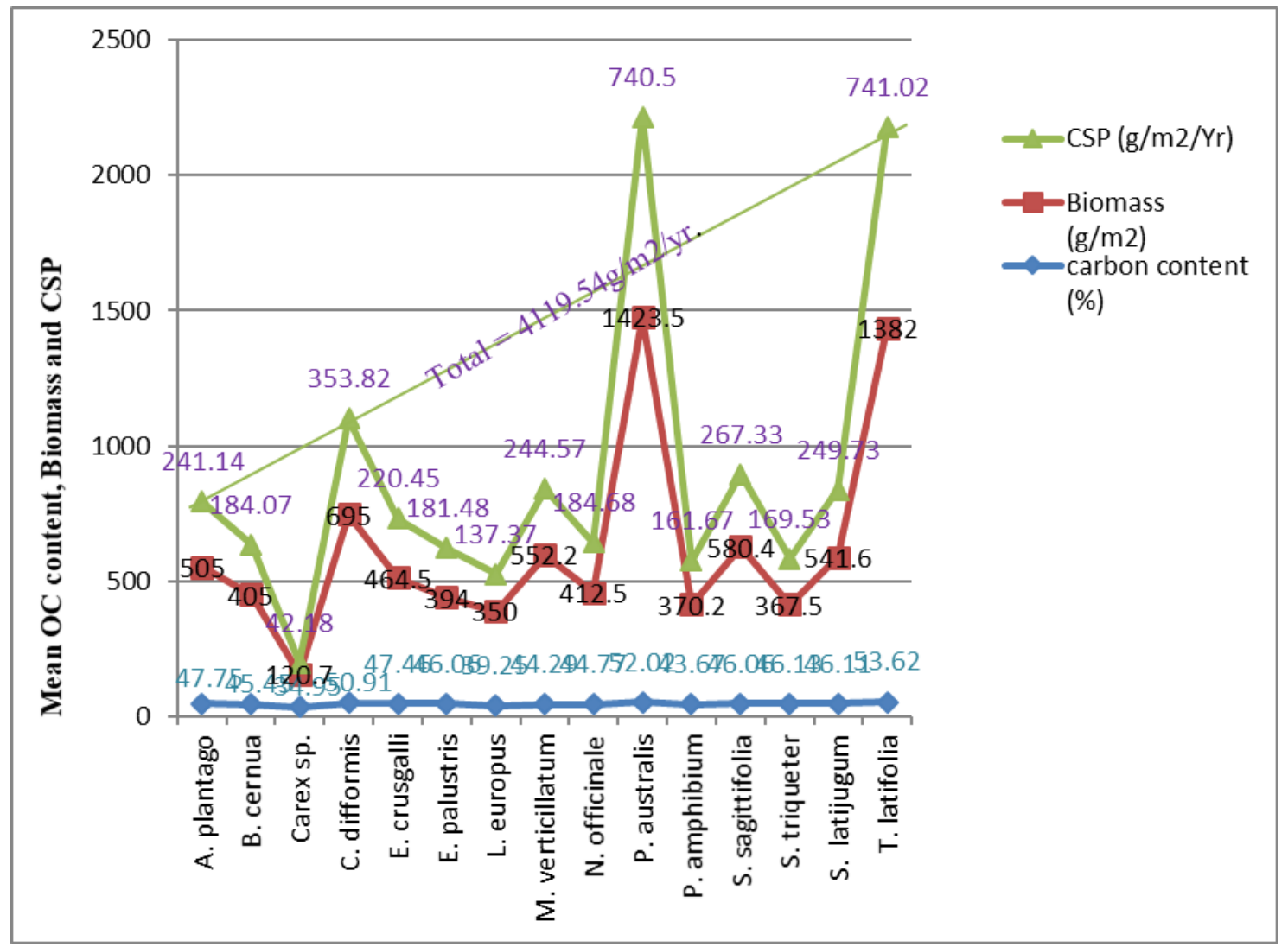

Figure 16. Mean carbon content, biomass and carbon sequestration of macrophytes (Mitsch et al., 2015)

Wang also reported $44.7 \%, 44.1 \%$ and $41.8 \%$ of carbon for Phragmites communis, Cyprus malaccensis, and Eleocharis dulcis, respectively which is lower than the values of Phragmites australis, Cyperus difformis, and Eleocharis palustris, respectively obtained by Khan and Maqubool (2014). These macrophytes species carbon content and hence their CSP was higher when compared with other reported results for Scirpus lacustris (44.12\%), Eleocharis palustris (43\%) (Fernández-Aláez et al., 1999); Phragmites australis (29.2\%) and Myriophyllum salsugineum (15.8\%) (Piola et al., 2008). Furthermore, Costa and Henry (2010) observed the highest carbon content for E. 
azurea (43.7\%), Myriophyllum aquaticum (43\%), Cyperus esculentus (41.6\%) and Polygonumspectable (38\%). Assuming $4119.54 \mathrm{gC} / \mathrm{m}^{2} / \mathrm{yr}$ as the rate of carbon sequestered in each year in this system, the limit for carbon emissions can be calculated to determine the point at which the system offsets carbon emission. To compare the physical sequestration and the gaseous emissions both are converted to carbon dioxide equivalents $\left(\mathrm{CO}_{2} \mathrm{e}\right)$ (Forster et al., 2007). The $\mathrm{CO}_{2} \mathrm{e}$ allows the comparison of different masses and gases as they relate to their greenhouse warming potential. Methane has 25 times the potential as $\mathrm{CO}_{2}$. Each gram of carbon is equivalent to $3.67 \mathrm{~g}$ of $\mathrm{CO}_{2}$. The $\mathrm{CO}_{2}$ equivalent of $4119.54 \mathrm{gC} / \mathrm{m}^{2} / \mathrm{yr}$. is $15118.7118 \mathrm{~g} \mathrm{CO}_{2}$. The methane equivalent to this amount of carbon sequestration is $604.748472 \mathrm{~g} / \mathrm{m}^{2} / \mathrm{yr}$. Constructed wetlands showing methane emission values less than $1,600 \mathrm{~kg} / \mathrm{ha} / \mathrm{yr}$ are considered as potential for carbon sequestration (Kayranli et al., 2010). Based on this argue, the above treatment plant has a carbon sequestration potential.

Constructed wetlands are purposely constructed in order to reduce input of nutrients and organic pollutants to water bodies. When these systems are used for wastewater treatment, microbial processes and gas dynamics are likely to be altered. With increased inputs of nutrients and organic pollutants, there is an increase in greenhouse gases production due to decomposition processes. Constructed wetlands therefore, can be sources of important greenhouse gases. The average $\mathrm{CH}_{4}, \mathrm{~N}_{2} \mathrm{O}$ and $\mathrm{CO}_{2}$ fluxes for surface flow constructed wetland were $2.9,1.05$, and $15.2 \mathrm{mg} / \mathrm{m}^{2} / \mathrm{h}$, respectively. Whereas the average higher fluxes were found from free water surface constructed wetland with average $\mathrm{CH}_{4}, \mathrm{~N}_{2} \mathrm{O}$ and $\mathrm{CO}_{2}$ fluxes at $5.9,1.8$, and $29.6 \mathrm{mg} / \mathrm{m}^{2} / \mathrm{h}$, respectively, corresponding to the average global warming potential (GWP) of $392 \mathrm{mg}$ $\mathrm{CO}_{2}$ equivalents $/ \mathrm{m}^{2} / \mathrm{h}$ and $698 \mathrm{mg} \mathrm{CO}$ equivalents $/ \mathrm{m}^{2} / \mathrm{h}$, respectively for SSFCW and FWSCW (Fig. 17) (Chuersuwan et al., 2014).

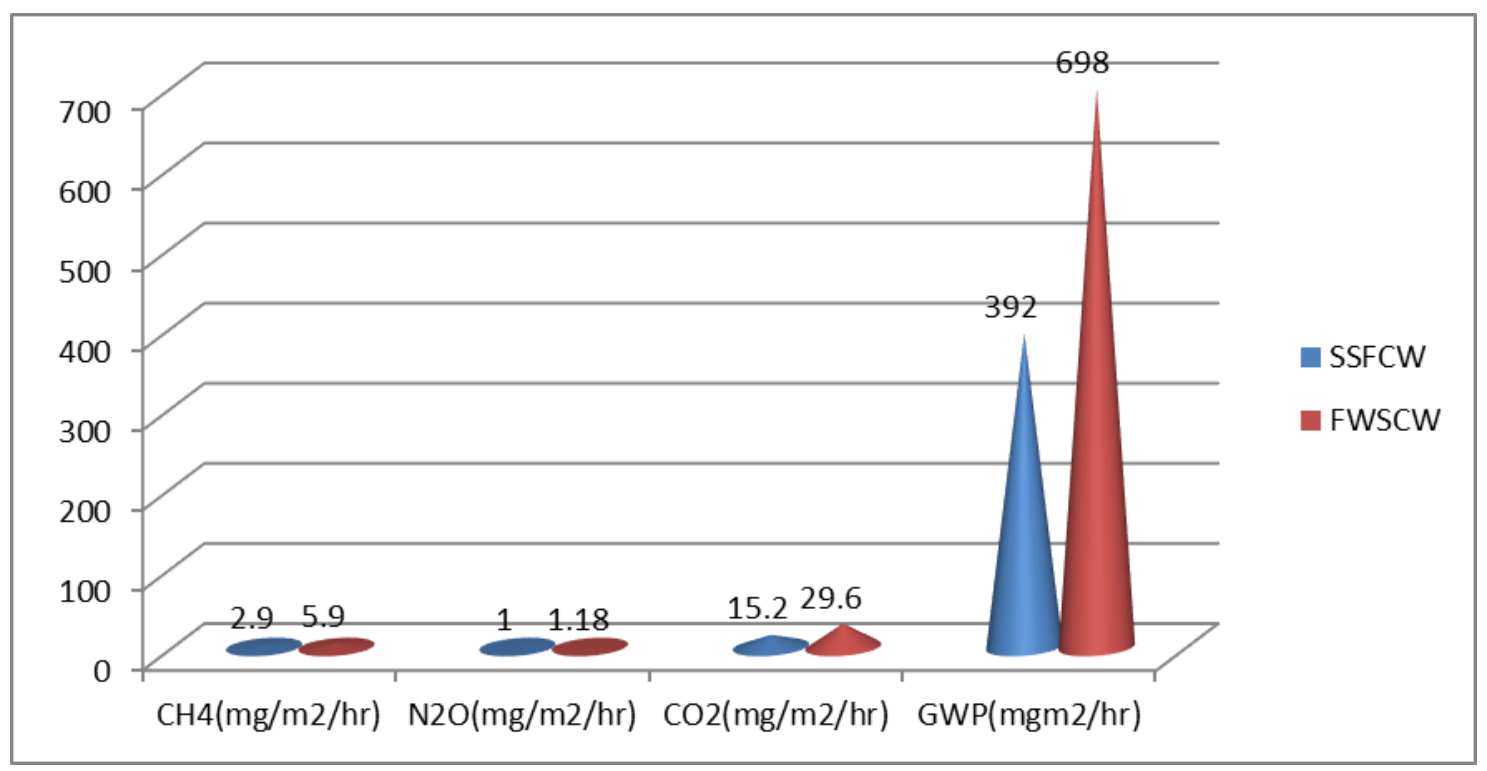

Figure 17. Comparison of greenhouse gas emissions and GWP of free water and subsurface flow CWs (Chuersuwan et al., 2014)

In another study by Maucieri et al. (2014), the comparison of vegetated and unvegetated horizontal subsurface flow constructed wetland effect on the $\mathrm{CO}_{2}$ (eq) 
balance showed a significant difference. The average $\mathrm{CO}_{2}$ emission of the whole monitored period were 15.5, 15.1, and $3.6 \mathrm{~g} \mathrm{~m}^{-2} \mathrm{~d}^{-1}$ for Arundox donax L. Phragmites australis and unvegetated beds, respectively. Whereas, cumulative estimated $\mathrm{CH}_{4}$ emissions during the study period were $159.5,134.1$ and $114.5 \mathrm{~g} \mathrm{~m}^{-2} \mathrm{~d}^{-1}$ for A. donax, $\mathrm{P}$. australis and unvegetated beds, respectively. $\mathrm{CO}_{2}$ (eq) balance showed that the two vegetated beds act as $\mathrm{CO}_{2}$ (eq) sinks, while the unvegetated bed act as $\mathrm{CO}_{2}$ (eq) source. Considering only the above-ground plant biomass in the $\mathrm{CO}_{2}$ (eq) budgets, P. australis and A. donax determined uptakes of 1.3 and $8.35 \mathrm{~kg} \mathrm{CO}_{2} \mathrm{~m}^{-2} \mathrm{~d}^{-1}$, respectively, and generally the plant biomass carbon content and the bed biomass yield in the vegetated cell fixed 11.61 and $27.03 \mathrm{kgCO}_{2}(\mathrm{eq}) \mathrm{m}^{-2} \mathrm{~d}^{-1}$, respectively for P. australis and A. donax, showing a positive balance, while the unvegetated bed had a negative balance (Fig. 18). Carbon dioxide and methane emissions and carbon budgets in a horizontal subsurface flow pilot constructed wetland with vegetated with C. papyrus and Chrysopogon zizanoids Roberty and Mischantus giagnteus, showed higher biomass accumulation in M. giganteus $\left(7.4 \mathrm{~kg} \mathrm{~m}^{-2}\right)$ followed by $\mathrm{C}$. zizanoids $\left(5.3 \mathrm{~kg} \mathrm{~m}^{-2}\right)$ and $\mathrm{C}$. papyrus $\left(1.8 \mathrm{~kg} \mathrm{~m}^{-2}\right)$.

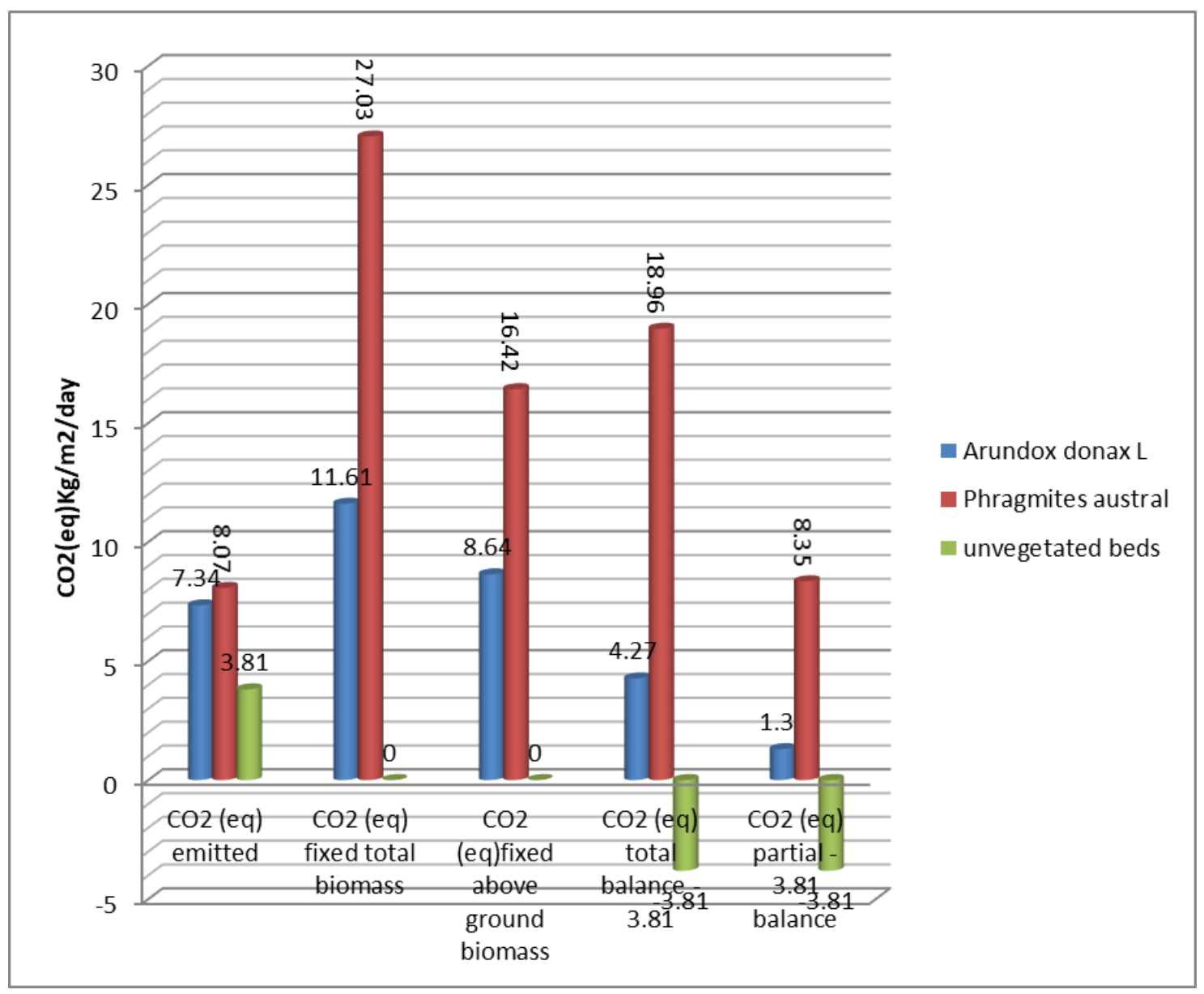

Figure 18. HSSFCW beds carbon dioxide equivalent balance (Maucieri et al., 2014)

The cumulative $\mathrm{CO}_{2}$ emissions by C. papyrus and C. zizanoids during the 1-year monitoring period showed similar trends with final volumes of about 775 and $1074 \mathrm{~g} \mathrm{~m}^{-2}$, respectively, whereas M. giganteus emitted 3,395 $\mathrm{g} \mathrm{m}^{-2}$. Cumulative methane emission 
showed the greatest methane emission for C. zizanoids bed with $240.3 \mathrm{~g} \mathrm{~m}^{-2}$ followed by $\mathrm{C}$. papyrus $\left(12 \mathrm{~g} \mathrm{~m}^{-2}\right)$ and $\mathrm{M}$. giganteus. The organic carbon abatment determined the carbon flux in the atmosphere. Gas fluxes were influenced both by plant species and monitored months with average carbon emitted to carbon removed ratio for $\mathrm{C}$. zizanoids, C. papyrus and M. giganteus of $0.3,0.5$ and 0.9 , respectively. The growing season carbon balances were positive for all vegetated beds with the highest carbon sequestered in the bed with $\mathrm{M}$. giganteus $\left(4.26 \mathrm{~kg} \mathrm{~m}^{-2}\right)$ followed by $\mathrm{C}$. zizanoids $\left(3.78 \mathrm{~kg} \mathrm{~m}^{-2}\right)$ and C. papyrus $\left(1.89 \mathrm{~kg} \mathrm{~m}^{-2}\right)$ in Figure 19.

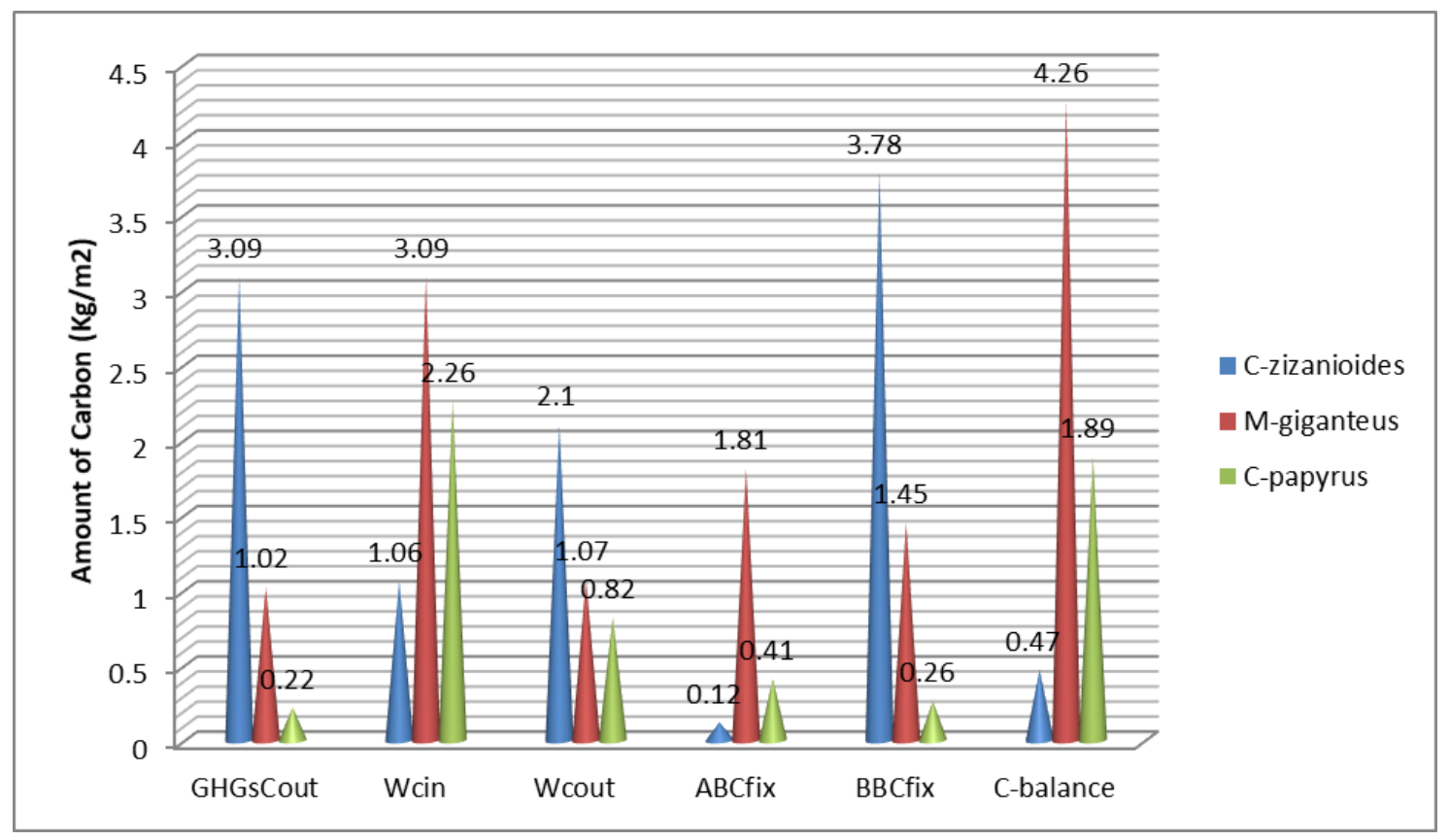

Figure 19. Carbon balance in $\mathrm{HSSFCW}$

\section{Conclusion}

The reviewed results showed that the HSSFCWs perform good removal efficiencies for organic matter and SS under low $\mathrm{C}: \mathrm{N}: \mathrm{P}$ loading conditions. Nowadays, the strategies of treating domestic and municipal wastewaters by decentralized way become common in rural and urban areas using constructed wetland technologies. Besides this, constructed wetlands are accepted as a reliable wastewater technology as post treatment of effluents. Because they are low cost, easily operated and maintained and have a strong prospective for application in developing countries.

Most research investigation results revealed that use of a subsurface horizontal flow phytoremediation treatment system is a promising natural technology in the treatment of municipal or industrial wastewater. Because, $\mathrm{CW}$ treatment system was found to comply with WHO (1989) standards for treated effluent reuse. Globally, the following abatement efficiencies were achieved by HSSFCW treatment system: 98\%, 96\%, 85\%, 90\%, 92\%, $88 \%$ for BOD5, COD, TSS, TN, $\mathrm{NH}_{4}-\mathrm{N}, \mathrm{PO}_{4}{ }^{3}$-, respectively in Kenya; $98.46 \%$ and 98.55\% for COD and BOD5 in Indonesia; and ranges from 94-99.9\%, 91.7-97.9\% and 99.99\% for $\mathrm{BOD}_{5}, \mathrm{COD}$ and TFC, respectively in Costa Rica. Whereas in Ethiopia, the HSSFCW achieved the following abatement efficiencies: COD ranges from 58 to $80 \%$, BOD ranges from 66 to $77 \%$, TKN ranges from 46 to $61 \%$, sulfates ranges from 53 to 
$82 \%$, and $\mathrm{NH}_{4}-\mathrm{N}$ ranges from 64 to $82.5 \%$ for tannery wastewater treatment. For domestic wastewater treatment; $99.3 \%, 89 \%, 855,84.05 \%, 77.3 \%, 99 \%$ and $94.5 \%$ were determined for BOD5, COD, TSS, TN, $\mathrm{PO}_{4}{ }^{3}$-TP, Sulfate, and TFC, respectively.

The pollutant removal efficiencies and greenhouse gas emissions from the CWs increased with the rise in temperature. The HSSF CWs had the highest tendency to emit $\mathrm{CH}_{4}$ and thus global warming potential of CWs, and the combined CWs by way of contrast showed low global warming potential. Due to the climate demonstrative of $\mathrm{CW}$ and periodic changes, further study to observe the seasonal fluctuations of $\mathrm{CH}_{4}$ and $\mathrm{N}_{2} \mathrm{O}$ emission is necessary. CWs have been found to be potential sinks of Carbon in terms of organic carbon. We face several significant questions regarding the potential for carbon sequestration in wetlands. Constructed wetlands can be managed as net carbon sinks over time. From the Reviewed results point of view, the net carbon gain and the biomass was comparatively higher, carbon storage in biomass and reduced $\mathrm{CO}_{2}$ emissions. For example, the City of Arcata sequesters carbon in all three treatment units at a rate equivalent of $80,000 \mathrm{~kg} \mathrm{CO} / \mathrm{yr}$. Most research investigation results revealed that horizontal subsurface flow constructed wetlands have been successfully employed to abate key contaminants from wastewater and able to meet the required standard discharge limits.

However, constructed wetland performance efficiency sustainability is affected by the operational conditions of HSSFCW including plant species, media/substrate types, water depth, hydraulic loading, and hydraulic retention time and feeding mode. Though the Total Carbon value at the $\mathrm{CW}$ is particularly beneficial for the growth of emergent macrophyte. CWs can be used to treat the wastewater from an industry or community development and also provide an additional benefit as green belts around the industries or the community development. By adopting these Biological CW treatment systems, we can not only achieve our plan of carbon emission reduction but also generate huge amount of savings and earn carbon credits too to ensure a Clean Development Mechanism.

\section{Recommendations}

In this paper, encouraging reviewed results were obtained on the role of HSSF CWs on the performance of climate mitigation and wastewater treatment. Based on this review, recommendations for the educational community and user of the technology are suggested. In order to obtain refined results for further long-term research on the performance of the wetlands with respect to all parameters using advanced sized wetland is essential. Besides, further analysis of carbon sequestration potential for climate mitigation and nitrification potential using the HSSF constructed wetlands is recommended for better results. For the user of the technology it can be chosen for application and their construction cost is evidently cheaper. However, evapotranspiration was peak and overstated during dry seasons in planted beds. Furthermore; it is worthwhile to use HSSFCW as one part of the treatment system to reduce GHG emission effect and infection before applying wastewater to recycle in irrigation.

\section{REFERENCES}

[1] Abdelhakeem, S. G., Aboulroos, S. A., Kamel, M. M. (2016): Performance of a vertical subsurface flow constructed wetland under different operational conditions. - Journal of Advanced Research 7: 803-814. 
[2] Akratos, C. S., Tsihrintzis, V. A. (2007): effect of temperature, HRT, vegetation and porous media on removal efficiency of pilot-scale horizontal subsurface flow constructed wetlands. - Ecological Engineering 29: 173-191.

[3] Andreo-Martínez, P., García-Martínez, N., Almela, L. (2016): Domestic wastewater depuration using a horizontal subsurface flow constructed wetland and theoretical surface optimization: a case study under dry Mediterranean climate. - Water Science 8: 434.

[4] Amenu, D. (2015): Evaluation of selected wetland plants for the removal efficiency of pollutants from waste water. - International Journal of Advanced Multidisciplinary Research - IJAMR 2(7): 63-66.

[5] Aregawi, T. (2014): Peculiar health problems due to industrial wastes In Addis Ababa City the case of Akaki Kality Industrial Zone. - M.Sc. Thesis, Addis Ababa University.

[6] Ayano, K. K. (2013): Effect of depth and plants on pollutant removal in Horizontal Subsurface flow constructed wetlands and their application in Ethiopia. - PhD Published Dissertation, Technische Universität Berlin. DOI: 10.14279/depositonce-3931.

[7] Bahri, A., Drechsel, P., Brissaud, F. (2008): Water reuse in Africa: challenges and opportunities. - CGIAR: A Repository of Agricultural Research Outputs, pp. 1-16. https://hdl.handle.net/10568/38135.

[8] Bahre, A. M. (2013): Horizontal subsurface constructed wetland for removal of heavy metals from leachate using Phragmite australis (a case of Addis Ababa solid waste open dump). - Published MSc. Thesis, Addis Ababa University.

[9] Baldizon, M., Dolmus, R., Quintana, J., et al. (2002): Comparison of conventional and macrophyte-based systems for the treatment of domestic wastewater. - Water Science and Technology 45: 111-116.

[10] Ballesteros, J. F., Vuong, T. H., Secondes, M. F., Tuan, P. D. (2016): Removal efficiencies of constructed wetland and efficacy of plant on treating benzene. Sustainable Environment Research 26(2): 93-96.

[11] Barbera, A. C., Cirelli, G. L., Cavallaro, V., Di Silvestro, I., Pacifici, P., Castiglione, V., Toscano, A., Milani, M. (2009): Growth and biomass production of different plant species in two different constructed wetland systems in Sicily. - Desalination 246(1-3): 129-136.

[12] Bayrau, A., Boelee, E., Drechsel, P., Dabbert, S. (2008): Health impact of wastewater use in crop production in peri-urban areas of Addis Ababa: implication for policy. - Paper submitted to Environmental and Development Economics.

[13] Bekele, M. (2008): Determination of heavy metals concentration in the sediment cores, water hyacinths and water of Aba Samuel Lake. - M.Sc. thesis, Addis Ababa University.

[14] Belmont, M. A., Cantellano, E., Thompson, S., Williamson, M., Sanchez, A., Metcalfe, C. D. (2004): Treatment of domestic wastewater in a pilot-scale natural treatment system in Central Mexico. - Ecol. Eng. 23(4-5): 299-311.

[15] Belmont, M. A., Zurita, F., De Anda, J. (2009): Treatment of domestic wastewater and production of commercial flowers in vertical and horizontal subsurface-flow constructed wetlands. - Ecological Engineering 35(5): 861-869.

[16] Beyene, A., Addis, T., Kifle, D. et al. (2009): Comparative study of diatoms and macroinvertebrates as indicators of severe water pollution: case study of the Kebena and Akaki Rivers in Addis Ababa, Ethiopia. - Ecological Indicators 9: 381-392.

[17] Birhanu, G., Seyoum, L. (2007): Constructed wetland system for domestic wastewater treatment: a case study in Addis Ababa, Ethiopia. https://www.amazon.com/Constructed-Wetland-Domestic-WastewaterTreatment/dp/3846504394.

[18] Brix, H., Schierup, H. H. (1989): The use of aquatic macrophytes in water-pollution control. - Ambio. Stockholm 18: 100-107.

[19] Brix, H., Arias, C. A., Del Bubba, M. (2001): Media selection for sustainable phosphorus removal in subsurface flow constructed wetlands. - Water Science and Technology 44(11-12): 47-54. 
[20] Burke, C. M. (2011): An assessment of carbon, nitrogen and phosphorus storage and the carbon sequestration potential in Arcata's constructed wetland for wastewater treatment. - Published MSc Thesis, Humboldt State University.

[21] Bwire, K., Njau, K., Minja, R. (2011): Use of vetiver grass constructed wetland for treatment of leachate. - Water Science and Technology 63: 924-930.

[22] Chazarenc, F., Gagnon, V., Comeau, Y., Brisson, J. (2009): Effect of plant and artificial aeration on solids accumulation and biological activities in constructed wetlands. - Eco. Eng 35(6): 1005-1010.

[23] Chen, Z., Wu. S., Braeckevelt, M., Paschke, H., Kästner, M., Köser, H., Kuschk, P. (2012): Effect of vegetation in pilot-scale horizontal subsurface flow constructed wetlands treating sulphate rich groundwater contaminated with a low and high chlorinated hydrocarbon. - Chemosphere 89(6): 724-731.

[24] Chuersuwan, S., Suwanwaree, P., Chuersuwan, N. (2014): Estimating greenhouse gas fluxes from constructed wetlands used for water quality improvement. - Songklanakarin Journal of Science \& Technology 36(3): 46-55.

[25] Costa, R. L. M., Raoul Henry, R. (2010): Phosphorus, nitrogen, and carbon contents of macrophytes in lakes lateral to a tropical river, Paranapanema River Paulo. - Brazil Journal of Acta Limnologica Brasiliensia 22(2): 122-132.

[26] Cooper, F. P., Boon, G. A. (1987): The Use of Phragmites for Wastewater Treatment by Root Zone Method: The UK Approach. - In: Reddy, R. K., Smith, H. W. (eds.) Aquatic Plants for Wastewater Treatment and Resource Recovery. Mangnolia Publishing, Orlando, pp. 153-174.

[27] Haberl, R. (1999): Constructed wetlands: a chance to solve wastewater problems in developing countries. - Water Science and Technology 40(3): 11-17.

[28] Dadan, S. W., Taufiq, H., Dadan, S., Bento, K. T. B., Denny, K. (2016): A review on subsurface flow constructed wetlands in tropical and sub-tropical countries. - Open Science Journal. https://osjournal.org/ojs/index. php/OSJ/ article/download/415/24.

[29] Denny, P. (1997): Implementation of constructed wetlands in developing countries. Water Science and Technology 35(5): 27-34.

[30] Donald, A. H. (1989): Constructed Wetlands for Wastewater Treatment: Municipal, Industrial and Agricultural. - Lewis Publishers, Chelsea, MI. https://www.crcpress.com/Constructed-Wetlands-for-Wastewater-Treatment-MunicipalIndustrial-and/Hammer/p/book/9780873711845.

[31] El Gohary, R. (2008): Restoration of chemical, bacteriological characterization for drainage water: case study. - Ain Shams Engineering Journal 1: 15-32.

[32] El Hamouri, B., Nazih, J., Lahjouj, J. (2007): Subsurface-horizontal flow constructed wetland for sewage treatment under moroccan climate conditions. - Desalination 215(13): $153-158$.

[33] El-Khateeb, M. A., El-Bahraw, A. Z. (2013): Extensive post treatment using constructed wetland. - Life Science Journal 10(2): 560-568.

[34] Elias, E., Yohannes, H. (2017): Contamination of rivers and water reservoirs in and around Addis Ababa City and actions to combat it. - Environ Pollution and Climate Change 1(2): 1-13.

[35] Farzadkia, M., Ehrampoush, M. H., Mehrizi, E. A., Sadeghi, S., Talebi, P., Salehi, A., Kermani, M. (2015): Investigating the efficiency and kinetic coefficients of nutrient removal in the subsurface artificial wetland of yazd wastewater treatment plant, environmental. - Health Engineering and Management 2(1): 23-30.

[36] Fernández-Aláez, C., Fernández-Aláez, M., Bécares, E. (1999): Influence of water level fluctuation on the structure and composition of the macrophyte vegetation in two small temporary lakes in the northwest of Spain. - BMC Biology, Ecology and Management of Aquatic Plants 415: 155-162. 
[37] Florentina, Z., John, R. W. (2014): Comparative study of three two-stage hybrid ecological wastewater treatment systems for producing high nutrient, reclaimed water for irrigation reuse in developing countries. - Water 6: 213-228.

[38] Forster, P., et al. (2007): Changes in Atmospheric Constituents and in Radiative Forcing. - In: Climate Change. The Physical Science Basis. Contribution of Working Group I to the Fourth Assessment Report of the Intergovernmental Panel on Climate Change. Cambridge University Press, Cambridge.

[39] Garcia, J., Chiva, J., Aguirre, P., Alvarez, E., Pau Sierra, J., Mujeriego, R. (2004): Hydraulic behaviour of horizontal subsurface flow constructed wetlands with different aspect ratio and granular medium size. - Ecological Engineering 23(3): 177-187.

[40] Gearheart, R. (2004): planning and preliminary technical study for the application of a wetland treatment system at the city of Fort Bragg wastewater facility. https://city.fortbragg.com/DocumentCenter/View/3574/Mill-Pond-Marsh-Report?bidId=.

[41] Ghermandi, A., Van Den Bergh, J. C. J. M., Brander, L. M., de Groot, H. L. F., Nunes, P. L. A. D. (2010): Values of natural and human - made wetlands: a meta - analysis. Water Resources Research 46(12): 1-12.

[42] Gonzalez, T. F., Vallejos, G. G., Silveira, H. J., Franco, Q. C., Garcia, J., Puigagut, J. (2009): Treatment of swine wastewater with subsurface flow constructed wetlands in Yucatan, Mexico: influence of plant species and contact time. - Water SA 35: 333-341.

[43] Grünfeld, S., Brix, H. (1999): Methanogenesis and methane emissions: effects of water table, substrate type and presence of Phragmites australis. - Aquatic Botany 64: 63-75.

[44] Gui, P., Inamori, R., Matsumura, M., et al. (2007): Evaluation of constructed wetlands by wastewater purification ability and greenhouse gas emissions. - Water Science and Technology 56: 49-55.

[45] Haberl, R., (1999): Constructed wetlands: a chance to solve wastewater problems in developing countries. - Water Science and Technology 40(3): 11-17.

[46] Huang, J., Reneau, R., Hageborn, C. (2000): Nitrogen removal in constructed wetlands employed to treat domestic wastewater. - Water Res. 34: 2582-2588.

[47] Itanna, F. (2002): metals in leafy vegetables grown in Addis Ababa and toxicological implications. - Ethiopian Journal of Health Development 16: 295-302.

[48] Johansson, A. E., Kasimir-Klemedtsson, A., Klemedtsson, L., Svensson, B. H. (2003): nitrous oxide exchanges with the atmosphere of a constructed wetland treating wastewater. - Tellus B 55(3): 737-750.

[49] Kadlec, R. H. (2003): Effects of pollutant speciation in treatment wetlands design. Ecological Engineering 20: 1-16.

[50] Kadlec, R. H., Wallace, S. (2008): Treatment Wetlands. 2nd Ed. - CRC Press, Boca Raton.

[51] Kambole, M. S. (2003): Managing the water quality of the Kafue River. - Physics and Chemistry of the earth, Parts A/B/C 28: 1105-1109.

[52] Kanungo, P., Kumawat, D. M., Billore, S. K. (2017): Potential of constructed wetlands to reduce and assimilate total organic carbon from municipal wastewaters. - Indian Journal of Environmental Sciences 21(1): 35-44.

[53] Kassa, A. (2012): Challenges and opportunities of riverbank urban agriculture. http://localhost:80/xmlui/handle/123456789/885.

[54] Kassa, Y., Mengistou, S. (2014): Nutrient uptake efficiency and growth of two aquatic macrophyte species under constructed wetlands, Ethiopia. - THIOP. J. Sci. 37: 95-104.

[55] Kathleen, L. M. (2000): Analysis of residential subsurface flow constructed wetlands performance in northern Alabama. - Small Flows Quarterly 1(3): 34-39.

[56] Kayranli, B., Scholz, M., Mustafa, A., et al. (2010): Carbon storage and fluxes within freshwater wetlands: a critical review. - Wetlands 30: 111-124. 
[57] Khan, J., Maqbool, T. S., Lee, C.-H. (2014): Effects of filtration modes on membrane fouling behavior and treatment in submerged membrane bioreactor. - Bioresource Technology 172: 391-395.

[58] Khiatuddin, M. 2003. Melestarikan Sumber Daya Air Dengan Teknologi Rawa Buatan. Gajah Mada University Press, Yogyakarta.

[59] Knox, A. S. D., Nelson, E., Specht, W., Paller, M., Seaman, J. (2004): Metals Retention in Constructed Wetland Sediments. - Report WSRC-MS-2004-00444, U. S. Department of Energy, Oak Ridge, TN.

[60] Kotti, I. P., Gikas, G. D., Tsihrintzis, V. A. (2010): Effect of operational and design parameters on removal efficiency of pilot-scale FWS constructed wetlands and comparison with HSF systems. - Ecological Engineering 36(7): 862-875.

[61] Kröpfelová, L., Vymazal, J. (2008): Wastewater Treatment in Constructed Wetlands with Horizontal Sub-Surface Flow. - Springer Science \& Business Media, Dordrecht.

[62] Kuschk, P., Kappelmeyer. U., Weixbrodt, E., Kästner, M., Stottmeister, U. (2003): Annual cycle of nitrogen removal by a pilot-scale subsurface horizontal flow in a constructed wetland under moderate climate. - Water Research 37(17): 4236-4242.

[63] Kyambadde, J., Kansiime, F., Dalhammar, G. (2005): Nitrogen and phosphorus removal in substrate-free pilot constructed wetlands with horizontal surface flow in Uganda. Water, Air, and Soil Pollution 165: 37-59.

[64] Lakshman, G. 1987 Ecotechnological Opportunities for Aquatic Plants: A Survey of Utilization Options. - Saskatchewan Research Council, Saskatoon, Saskatchewan, Canada.

[65] Langergraber, G. (2013): Constructed treatment wetlands sustainable sanitation solutions. - Water Science and Technology 67(10): 2133-2140.

[66] Lopez-Lopez, A., Vallejo-Rodríguez, R., León-Becerril, E., López-Rivera, A. (2015): Effect of the organic loading rate in the stillage treatment in a constructed wetland with Canna Indica. - Environmental Progress \& Sustainable Energy 35(2): 411-415.

[67] Liu, C., Xu, K., Inamori, R., Ebie, Y., Liao, J. (2009): Pilot-scale studies of domestic wastewater treatment by typical constructed wetlands and their greenhouse gas emissions. - Environ. Sci. Engin. 3(4): 477-482.

[68] Luckeydoo, L. M., Fausey, N., Brown, L. et al. (2002): Early development of vascular vegetation of constructed wetlands in Northwest Ohio receiving agricultural waters. Agriculture, Ecosystems \& Environment 88: 89-94.

[69] Mahmoud, K., Baskar, G. (2018): Constructed wetlands for wastewater treatment. Journal of Modern Science and Technology 6(1): 78-86.

[70] Mairi, P. J., Lyimo, J. T., Njau, N. K. (2012): Performance of subsurface flow constructed wetland for domestic wastewater treatment. - Tanz. J. Sci. 38: 67-76.

[71] Mander, Ü., Lõhmus, K., Teiter, S., Nurk, K., Mauring, T., Augustin, J. (2005): Gaseous fluxes from subsurface flow constructed wetlands for wastewater treatment. - J. Environ. Sci. Health A. 40(6-7): 1215-1226.

[72] Mander, U., Lõhmus, K., Teiter, S., Mauring, T., Nurk, K., Augustin, J. (2008): Gaseous fluxes in the nitrogen and carbon budgets of subsurface flow constructed wetlands. - Sci. Total Environ. 404(2-3): 343-353.

[73] Mander, Ü., Maddison, M., Soosaar, K., Karabelnik, K. (2011): The impact of intermittent hydrology and fluctuating water table on greenhouse gas emissions from subsurface flow constructed wetlands for wastewater treatment. - Wetlands 1023-1032.

[74] Maqbool, T., Jamal Khan, S., Lee, C-H. (2014): Effects of filtration modes on membrane fouling behavior and treatment in submerged membrane bioreactor. - Bioresource Technology 172: 391-395.

[75] Mariñelarena, A. J., Di Giorgi, H. D. (2001): Nitrogen and phosphorus removal by periphyton from agricultural wastes in artificial streams. - Journal of Freshwater Ecology 16: 347-353. 
[76] Maucieri, C., Borin, M., Barbera, A. C. (2014): Role of C3 plant species on carbon dioxide and methane emissions in Mediterranean constructed wetland. - Italian Journal of Agronomy 9: 120-126.

[77] Michael, J. C.' Lori, W., Kathleen, C. P. (2006): Patterns of vertical stratification in a subtropical constructed wetland in South Florida (USA). - Ecological Engineering 27(4): 322-330.

[78] Mitsch, W. J., Bernal, B., Hernandez. M. E. (2015): Ecosystem services of wetlands. International Journal of Biodiversity Science, Ecosystem Services \& Management 11(1): $1-4$.

[79] Mustafa, A. (2013): Constructed wetland for wastewater treatment and reuse: a case study of developing country. - International Journal of Environmental Science and Development 4(1): 20-24.

[80] Nyakango, J. J. (1999): Combination of a well-functioning constructed wetland with a pleasing landscape design in Nairobi, Kenya. - J. Water Science and Technology 40: 247-247.

[81] Oostrom, J (1994): Denitrification in constructed wastewater wetlands receiving high concentrations of nitrate. - Water Sci. Technol 7-14.

[82] Panrare, A., Prapa, S., Tusanee, T. (2015): Constructed wetland for sewage treatment and thermal transfer reduction. - Energy Procedia 79: 567-575.

[83] Piola, R. F., Suthers, I. M., Rissik, D. (2008): Carbon and nitrogen stable isotope analysis indicates fresh water shrimp Paratya australiensis Kemp, 1917 (Atyidae) assimilate cyanobacterial accumulations. - Hydrobiologia 608(1): 121-132.

[84] Prasad, B., Maiti, D. (2016): Comparative study of metal uptake by Eichhornia crassipes growing in ponds from mining and nonmining areas - a field study. - Bioremediation Journal 20(2): 144-152.

[85] Prasad, R., Rangari, P. J., Jasutkar, D. (2016): Performance evaluation of constructed wetland in treating domestic wastewater. - International Journal of Latest Research in Engineering and Technology 2(5): 28-33.

[86] Pucci, B., Conte, G., Martinuzzi, N., Giovannelli, L., Masi, F. (2000): Design and performance of a horizontal flow constructed wetland for treatment of diary and agricultural wastewater in the Chianti countryside. https://pdfs.semanticscholar.org/edea/90e784d52cf07695cebfaa79399a9b7af9d5.pdf?_ga $=2.126156365 .1936323412 .1579619295-814467461.1579619295$.

[87] Puigagut, J., Villaseñor, J., José Salas, J., Bécares, E., García, J. (2007): Subsurface-flow constructed wetlands in Spain for the sanitation of small communities: a comparative study. - Ecological Engineering 30(4): 312-319.

[88] Qomariyah, S. Sobriyah, S., Ramelan, A. H., Setyono, P. (2017): Use of macrophyte plants, sand and gravel materials in constructed wetlands for greywater treatment. IOP Conf. Series. - Materials Science and Engineering 176: 1-7.

[89] Reddy, K., Debusk, W. (1991): Decomposition of water hyacinth detritus in eutrophic lake water. - Hydrobiologia 211: 101-109.

[90] Richardson, W. B., Straauss, E. A., Bartsch, L. A., Monroe, E. M., Cavanaugh, J. C., Vingum, L., Soballe, D. M. (2004): Denitrification in the upper Mississippi River: rate, controls, and contribution to nitrate flux. - Can. J. Fish. Aquat. Sci. 61: 1102-1112.

[91] Rosso, D., Stenstrom, M. K. (2008): The carbon-sequestration potential of municipal Wastewater treatment. - Chemosphere 8: 1468-1475.

[92] Saeed, T., Sun, G. (2012): A review on nitrogen and organics removal mechanisms in subsurface flow constructed wetlands: dependency on environmental parameters, operating conditions and supporting media. - Journal of Environmental Management 112: $429-448$.

[93] Sahu, O. (2014): Reduction of heavy metals from wastewater by wetland. - International Letters of Natural Sciences 12: 35-43. DOI: 10.18052/www.scipress.com/ILNS.12.35. 
[94] Sovik, A. K., Augustin, J., Hekkinen, K., Huttunen, J. (2006): Emission of the greenhouse gases nitrous oxide and methane from constructed wetlands in Europe. Journal of Environmental Quality 35(6): 2360-2373.

[95] Taylor, G. D., Fletcher, T. D., Wong, T. H. F., Duncan, H. P. (2006): Baseflow water quality behavior: implication for wetland performance monitoring. - Aust. J. Water Resour 10(3): 293-302.

[96] Terfie, T. A., Asfaw, S. L. (2014): Evaluation of selected wetland plants for removal of chromium from tannery wastewater in constructed wetlands, Ethiopia. - African Journal of Environmental science and technology 9(5): 420-427.

[97] Tilak, S. A., Wani, P. S., Patil, D. M., Datta, A. (2016): Evaluating wastewater treatment efficiency of two field scale subsurface flow constructed wetlands. - Current Science 110(9): 1764-1771.

[98] Tousignant, E., Fankhauser, O., Hurd, S. (1999): Guidance manual for the design, construction and operations of constructed wetlands for rural applications in Ontario. http://hdl.handle.net/10214/15203.

[99] UNEP/GPA - UNESCO-IHE (2004): Train-Sea-Coast GPA. A Joint UNESCO-IHE Improving Municipal Wastewater Management in Coastal Cities, The Netherlands. Version 01. - UNEP/GPA - UNESCO-IHE

[100] USEPA (1993): Subsurface Flow Constructed Wetlands for Wastewater Treatment. Technology Assessment. EPA 832-R-93-001.

[101] Van Der Zaag, A. C., Gordon, R. J., Burton, D. L., Jamieson, R. C., Stratton, G. W. (2010): Greenhouse gas emissions from surface flow and subsurface flow constructed wetlands treating dairy wastewater. - Journal of Environmental Quality 39(2): 460-471.

[102] Vymazal, J. (2005): Horizontal sub-surface flow and hybrid constructed wetlands systems for wastewater treatment. - Ecological Engineering 25: 478-490.

[103] Vymazal, J. (2007): removal of nutrients in various types of constructed wetlands. Science of The Total Environment 380(1-3): 48-65.

[104] Vymazal, J. (2011): Plants used in constructed wetlands with horizontal subsurface flow: a review. - Hydrobiologia 674: 133-156.

[105] Vymazal, J. (2013): The use of hybrid constructed wetlands for wastewater treatment with special attention to nitrogen removal: a review of a recent development. - Water Research 47: 4795-4811.

[106] Vymazal, J., Kröpfelová, L. (2008): Wastewater treatment in constructed wetlands with horizontal sub-surface flow. - Springer Science \& Business Media 14: 561.

[107] Wang, Y. C., Ko, C. H., Chang, F. C., Chen, P. Y., Liu, T. F., Sheu, Y. S., Shih, T. L., Teng, C. J. (2011): Bioenergy production potential for aboveground biomass from a subtropical constructed wetland. - Biomass and Bioenergy. 35: 50-58.

[108] Watson, J. T., Hobson, J. A. (1989): Hydraulic Design Considerations and Control Structures for Constructed Wetlands for Wastewater Treatment. - In: Hammer, D. A. (ed.) Constructed Wetlands for Wastewater Treatment. Lewis Publishers, Chelsea, MI.

[109] Whiting, G. J., Chanton, J. P. 2001. Greenhouse carbon balance of wetlands: methane emission versus carbon sequestration. - Tellus B 5: 521-528.

[110] Wijaya, S. D., Hidayat, T., Sumiarsa, D., Kurnaeni, B. T. B., Kurniadi, D. (2016): A Review on sub surface flow constructed wetlands in tropical and sub-tropical countries. Open Science Journal. DOI: 10.23954/osj.v1i2.415.

[111] Wu, S., Kusch, P., Hans, B. (2014): Development of constructed wetlands in performance intensification for wastewater treatment. A nitrogen and organic matter targeted. - Water Resources Research 57: 40-55.

[112] Zhu, A. Z. M., Qian, J. M., De Souza, M., Terry, N. (1999): Phytoaccumulation of trace elements by wetland plants: II. Water hyacinth. - Journal of Environmental Quality 28: 339-344. 


$$
-1089 \text { - }
$$

[113] Zurita, F., John, R. W. (2014): Comparative study of three two-stage hybrid ecological wastewater treatment systems for producing high nutrient, reclaimed water for irrigation reuse in developing countries. - Water 6: 213-228.

[114] Zurita, F., De Anda, J., Belmont, M. A. (2006): Performance of laboratory-scale wetlands planted with tropical ornamental plants to treat domestic wastewater. - Water Quality Research Journal Canada 41(4): 410-417.

[115] Zurita, F., De Anda, J., Belmont, M. A., Cervantes-Martinez, J. (2008): Stress detection by laser-induced fluorescence in Zantedeschia aethiopica planted in subsurface-flow treatment wetlands. - Ecological Engineering 33: 110-118. 